\title{
A Brief Review on Environmental Application of Boron Doped Diamond Electrodes as a New Way for Electrochemical Incineration of Synthetic Dyes
}

\author{
J. M. Peralta-Hernández, ${ }^{1}$ M. Méndez-Tovar, ${ }^{1}$ R. Guerra-Sánchez, ${ }^{1}$ \\ C. A. Martínez-Huitle, ${ }^{2}$ and J. L. Nava ${ }^{3}$ \\ ${ }^{1}$ Departamento de Investigación Ambiental, Centro de Innovación Aplicada en Tecnologías Competitivas, Omega 201, \\ Fraccionamiento Industrial Delta, 37545 León, Guanajuato, Mexico \\ ${ }^{2}$ Departamento de Química, Centro de Ciências Exatas e da Terra, Universidade Federal do Rio Grande do Norte, Lagoa Nova, \\ 59078-970 Natal, RN, Brazil \\ ${ }_{3}^{3}$ Departamento de Ingeniería Geomática e Hidráulica, Universidad de Guanajuato, Avenida Juárez 77, 36000, Guanajuato, Mexico
}

Correspondence should be addressed to J. M. Peralta-Hernández, jperalta@ciatec.mx

Received 29 April 2011; Revised 23 June 2011; Accepted 24 June 2011

Academic Editor: Yasuaki Einaga

Copyright () 2012 J. M. Peralta-Hernández et al. This is an open access article distributed under the Creative Commons Attribution License, which permits unrestricted use, distribution, and reproduction in any medium, provided the original work is properly cited.

\begin{abstract}
The present study was stimulated by an authoritative review on decontamination of wastewaters containing synthetic organic dyes by electrochemical methods published in Martínez-Huitle and Brillas (2009). As reviewed by the authors, there have been significant efforts on investigating the decontamination of wastewaters containing synthetic dyes by electrochemical methods, and currently, more studies are being published. A high number of electrodes have been tested in this method, including boron doped diamond (BDD) anodes. In this context, many papers have demonstrated that the use of a BDD thin film in electrochemical oxidation provides total mineralization with high current efficiency of different organics in real wastewaters. And this synthetic material deposited on several supports has been recently applied to dyestuff treatment. Although, in the last two years, more reports have been published treating electrochemically synthetic dyes wastewaters using BDD, there are few reports on the use of electrooxidation processes to degrade real textile effluents. The aim of this paper is to summarize and discuss the most important and recent results available in the literature about the application of BDD electrodes for removing azo dyes in synthetic and real wastewaters.
\end{abstract}

\section{Introduction}

Azo dyes are used in a wide variety of industrial processes such as, food production, cosmetics, and pharmaceuticals manufacturing and paper printing. Therefore, these dyes are frequently found in industrial wastewater effluents and are a principal cause of pollution around the world [1]. The release of colored effluents into the environment is undesirable, not only for aesthetic reasons but also because many azo dyes and their degradation byproducts are toxic to aquatic life and mutagenic to humans [2]. The effluents from the textile industry are frequently characterized by high alkalinity, biological oxygen demand, chemical oxygen demand, and total dissolved solids in addition to high dye concentrations (>1000 ppm). The synthetic origin and complex aromatic structures of dyes make them stable and difficult to biodegrade.

Dyes are classified as anionic (direct, acid, and reactive dyes), cationic (basic dyes), and nonionic (disperse dyes). The chromophores in ionic and nonionic dyes mostly consist of azo groups or anthraquinone types [3]. In this context, azo dye compounds constitute about one-half of the dyes that are used in the textile industry [4]. The chemical structure of this group of compounds is characterized by the presence of the azo group $(-\mathrm{N}=\mathrm{N}-)$ chromophore, associated with aromatic systems and other groups, such as hydroxyls $(-\mathrm{OH})$ and sulfonic groups $\left(-\mathrm{SO}_{3} \mathrm{H}\right)$ [5]. The azo group can be present one or more times in the molecular structure of the 
compound. Additionally, another environmental problem with respect to the use of azo dyes in the textile industry is the consumption of large amounts of potable water. In many countries where potable water is scarce, this high consumption of water has become undesirable, and wastewater recycling has been recommended in order to decrease the water requirements [2].

To avoid azo dye accumulation in aquatic systems, different methods are being developed to carry out the elimination of these compounds from wastewater. These include biological and physicochemical methods such as flocculation combined with flotation, membrane filtration, coagulation, ion exchange, irradiation, and katox treatment method [3, 6]. However, these methods are generally unsuccessful in color removal, expensive, and less adaptable to a wide range of dye wastewaters.

In recent years, electrochemical technologies have caused great interest because they offer effective means to solve environmental problems related to industrial processes $[7,8]$ such as wastewater contamination. The highest advantage of these methods is their environmental compatibility. Their principal reagent is the electron, which is an inherently clean species whose energy can be carefully controlled by means of an applied potential, thus avoiding parallel reactions. In traditional chemistry, secondary reactions often result in subproducts which sometimes increase removal costs [8-10].

The principal electrochemical methods are the following:

(a) direct electrochemical oxidation, where the organic compound degradation occurs directly over the anode trough the adsorbed ${ }^{\bullet} \mathrm{OH}$, or chemisorbed active oxygen in the anode surface (often called "anodic oxidation, direct oxidation or electrochemical incineration"), by means of the following general equation [10-12]:

$$
\mathrm{M}+\mathrm{H}_{2} \mathrm{O} \longrightarrow \mathrm{M}(\cdot \mathrm{OH})+\mathrm{H}^{+}+\mathrm{e}^{-},
$$

where the pollutants are first adsorbed on the anode surface $(\mathrm{M})$ and then destroyed by the anodic electron transfer reaction,

(b) indirect electrochemical oxidation, where the organic compounds are treated in the bulk solution by means of species generated in the electrode, such as ${ }^{\cdot} \mathrm{OH}$ (by means of the Fenton reaction), $\mathrm{Cl}_{2}$, hypochlorite, peroxodisulfate, and ozone, as the most common electrochemically generated oxidants $[6,13]$.

In recent decades, several electrodes have been evaluated to rank anode material in terms of high stability, high activity toward organic oxidation, and cost. The types of electrodes tested included graphite, platinum, $\mathrm{IrO}_{2}, \mathrm{RuO}_{2}$, $\mathrm{SnO}_{2}, \mathrm{PbO}_{2}, \mathrm{Ti} / \mathrm{Pt}, \mathrm{Ti} / \mathrm{Pt}-\mathrm{Ir}, \mathrm{Ti} / \mathrm{PbO}_{2}, \mathrm{Ti} / \mathrm{PdO}-\mathrm{Co}_{3} \mathrm{O}_{4}$, and $\mathrm{Ti} / \mathrm{RhO}_{x}-\mathrm{TiO}_{2}$, Ti coated with oxides of $\mathrm{Ru} / \mathrm{Ir} / \mathrm{Ta}[14,15]$, BDD thin films, and others.

In this context, several groups have proposed the use of BDD as anode material. The electrochemical behavior of such BDD thin films deposited on different substrates $(\mathrm{Si}, \mathrm{Ti}, \mathrm{Nb}$, or $\mathrm{Pt}$ ) has also been studied with the aim of

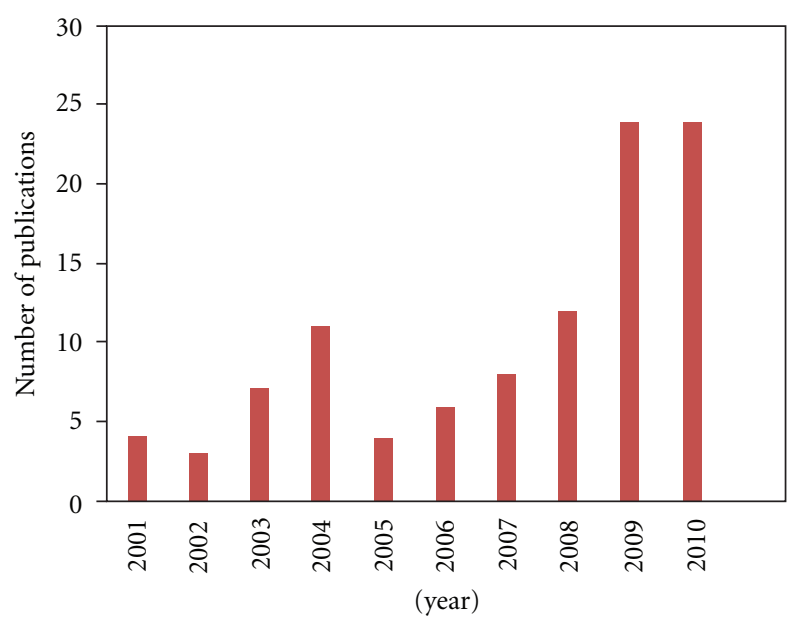

FIgURE 1: Tendency in the number of publications versus year for wastewater treatment using BDD anodes.

developing applications for the electrochemical oxidation of different organic compounds for wastewater treatment, as reviewed by Martinez-Huitle and Brillas [16], there have been significant efforts made in investigating the decontamination of wastewaters containing synthetic dyes by electrochemical methods, using especially BDD anodes. Although more reports involving electrochemical treatment of synthetic dye wastewater have been published in the last two years, there are few reports on the use of this process to degrade real textile effluents. The aim of this paper is to present the recent progress in electrochemical treatment by anodic oxidation of synthetic dye wastewaters and real effluents using BDD electrodes, focusing on the elimination of azo dyes.

\section{BDD Anodes for Wastewater Treatment Applications}

In the last 10 years, the boron-doped diamond anode has been an attractive material for numerous environmental applications. Figure 1 illustrates the tendency to use this kind electrode for the degradation of different refractory or priority pollutants in wastewater. Although relatively few articles were published between 2001 and 2005, the amount of articles involving BBD electrodes increased considerably between 2006 and 2010 (by means of Scopus).

2.1. Hydroxyl Radical $(B D D(\cdot \mathrm{OH}))$ Generation. Considerable ${ }^{\bullet} \mathrm{OH}$ amounts may be electrogenerated on BDD anodes. These radicals, due to their weak interaction with the BDD film, present high reactivity towards organics $(\mathrm{Rx} 2-4)$; these processes have been efficiently used in wastewater treatment $[10,17]$ as follows:

$$
\mathrm{BDD}+\mathrm{H}_{2} \mathrm{O} \longrightarrow \mathrm{BDD}(\cdot \mathrm{OH})+\mathrm{H}^{+}+\mathrm{e}^{-},
$$

$$
\mathrm{BDD}(\cdot \mathrm{OH})+\mathrm{R} \longrightarrow \mathrm{BDD}+m \mathrm{CO}_{2}+n \mathrm{H}_{2} \mathrm{O} .
$$




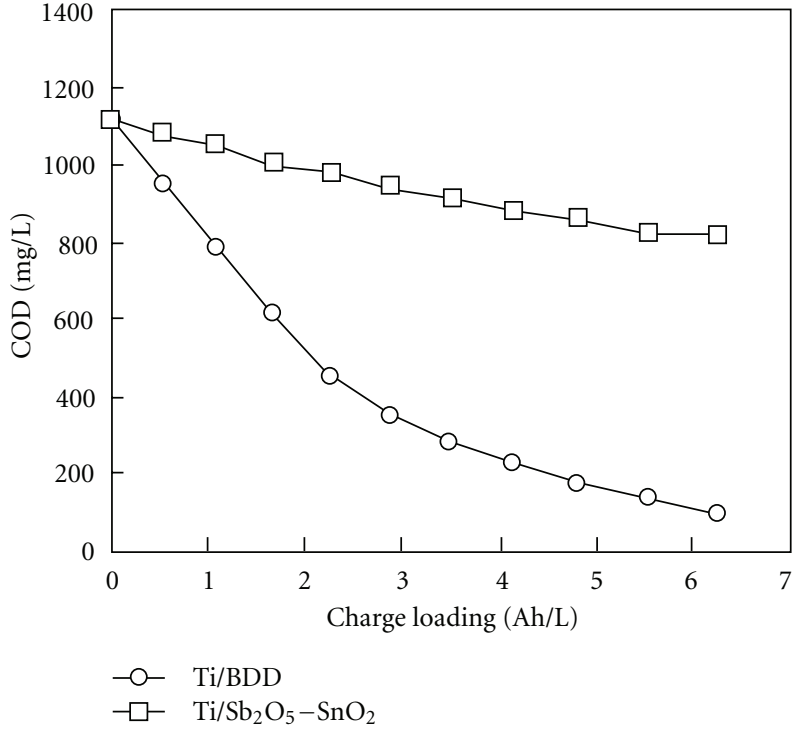

(a)

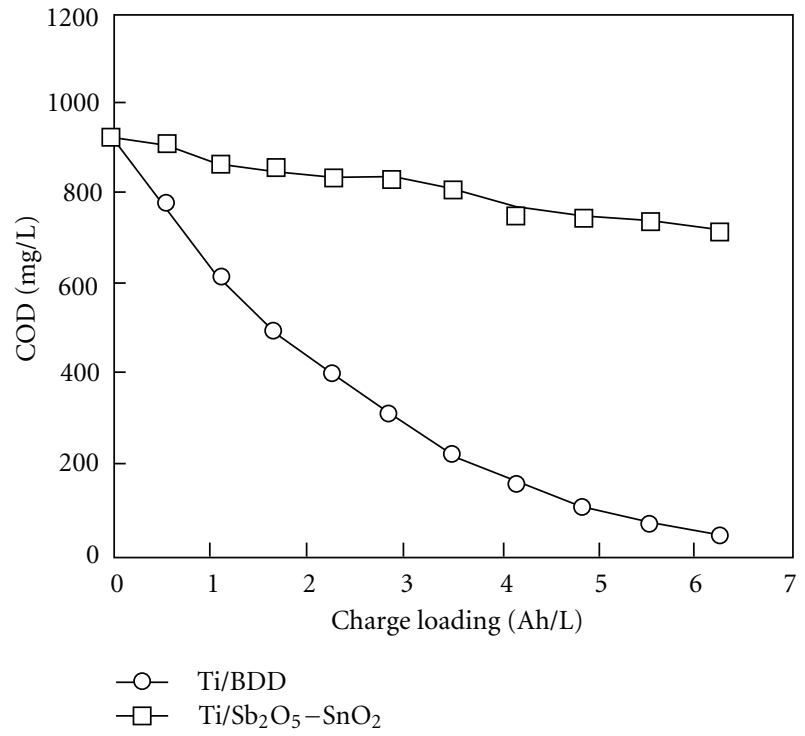

(b)

Figure 2: COD decay for comparison of Ti/BDD versus $\mathrm{Ti} / \mathrm{Sb}_{2} \mathrm{O}_{5}-\mathrm{SnO}_{2}$ for incineration (a) Orange II and (b) Reactive red $\mathrm{HE}-3 \mathrm{~B}$ at current density $200 \mathrm{~A} / \mathrm{cm}^{2}$ and $T=30^{\circ} \mathrm{C}$ [19].

According to the literature, reaction (3) is in competition with the side reaction of free ${ }^{\bullet} \mathrm{OH}$ discharge to $\mathrm{O}_{2}$ without any participation of $\mathrm{BDD}$ surface, following the next reaction:

$$
\mathrm{BDD}(\cdot \mathrm{OH}) \longrightarrow \mathrm{BDD}+\frac{1}{2} \mathrm{O}_{2}+\mathrm{H}^{+}+\mathrm{e}^{-} .
$$

However, many authors have reported that during incineration process of BDD anodes at high potentials, a great number of organic pollutants are completely mineralized by the reaction with electrogenerated free ${ }^{\bullet} \mathrm{OH}$ species [18]. In this context, some papers have reported (period from 2003 to 2010) the incineration of a great number of synthetic azo dyes by reaction with electrogenerated ${ }^{\circ} \mathrm{OH}$ species over BDD anode.

\subsection{Electrochemical Treatment of Synthetic Dye Solutions.} The study of the treatment of synthetic dyes using BDD anodes started in 2003, when Chen and coworkers [19] tested the mineralization of Orange II and Reactive red HE-3B. They proposed the comparison of physicochemical and electrochemical properties for two different electrodes, $\mathrm{Ti} / \mathrm{BDD}$ and $\mathrm{Ti} / \mathrm{Sb}_{2} \mathrm{O}_{5}-\mathrm{SnO}_{2}$, using a thermostatic reactor controlled with a water bath. They evaluated the efficiency for mineralization of $750 \mathrm{mg} / \mathrm{L}$ of Orange II and $1500 \mathrm{mg} / \mathrm{L}$ of Reactive red HE-3B in each electrode, measuring the chemical oxygen demand (COD) decay using a supporting electrolyte, $2 \mathrm{~g} / \mathrm{L}$ of $\mathrm{Na}_{2} \mathrm{SO}_{4}$. It was observed that the rate of COD decay considerably increased when the Ti/BDD electrode was used. Figure 2(a) shows that the decay of Orange II at the Ti/BDD anode was $91 \%$, and this removal efficiency was higher than that obtained at the $\mathrm{Ti} / \mathrm{Sb}_{2} \mathrm{O}_{5}-\mathrm{SnO}_{2}$ anode (26\%). In the case of Reactive red HE-3B, Figure 2(b) shows that the performance of COD abatement was very similar.
The Ti/BDD electrode achieved about $95 \%$ removal, whereas $\mathrm{Ti} / \mathrm{Sb}_{2} \mathrm{O}_{5}-\mathrm{SnO}_{2}$ only $22 \%$. In light of these results, $\mathrm{Ti} / \mathrm{BDD}$ anodes are much more efficient than those composed of $\mathrm{Ti} / \mathrm{Sb}_{2} \mathrm{O}_{5}-\mathrm{SnO}_{2}$.

After that, this application motivated other researchers to investigate the use of $\mathrm{BDD}$ anodes for removing dyes from synthetic wastewaters, such as the degradation of the azo dye Eriochrome Black T (EBT) by Cañizares et al. [20]. Figure 3 shows the abatement of $100 \mathrm{mg} / \mathrm{dm}^{3}$ of EBT where TOC $70 \%$ and COD $90 \%$, after that $20 \mathrm{Ah} \mathrm{dm}^{-3}$ was applied. When $1813 \mathrm{mg} / \mathrm{dm}^{3}$ has been treated, both TOC and COD decreased considerably after $80 \mathrm{~A} \mathrm{~h} \mathrm{dm}^{-3}$, achieving closely $100 \%$ of degradation. During the BDD oxidation of EBT molecules, a great variety of intermediates (changes in the COD) was observed, attaining complete incineration at the final electrolysis time. Sakalis et al. [21] compared the use of two different anodes: platinized titanium $(\mathrm{Pt} / \mathrm{Ti})$ and Niobium/synthetic diamond $(\mathrm{Nb} / \mathrm{D})$, in order to improve the electrochemical incineration of synthetic samples containing four reactive azo dyes. Different experimental conditions were evaluated, such as supporting electrolyte, concentration of electrolyte, effect of applied potential, $\mathrm{pH}$, and temperature. Under the optimum electrochemical conditions, complete elimination of dyes was achieved, using both electrodes $\mathrm{Pt} / \mathrm{Ti}$ and $\mathrm{Nb} / \mathrm{D}$. However, the use of $\mathrm{Nb} / \mathrm{D}$ anodes showed the best performances on removal efficiency for the most important parameters such as biochemical oxygen demand $\left(\mathrm{BOD}_{5}\right), \mathrm{COD}$, and TOC.

The influence of the anode on the electrochemical oxidation of methylene blue (MB) was evaluated by Panizza et al. [22]. Direct electrolysis using boron-doped diamond and the indirect electrolysis mediated by active chlorine electrogenerated on a $\mathrm{TiRuO}_{2}$ oxide anode, was compared for 


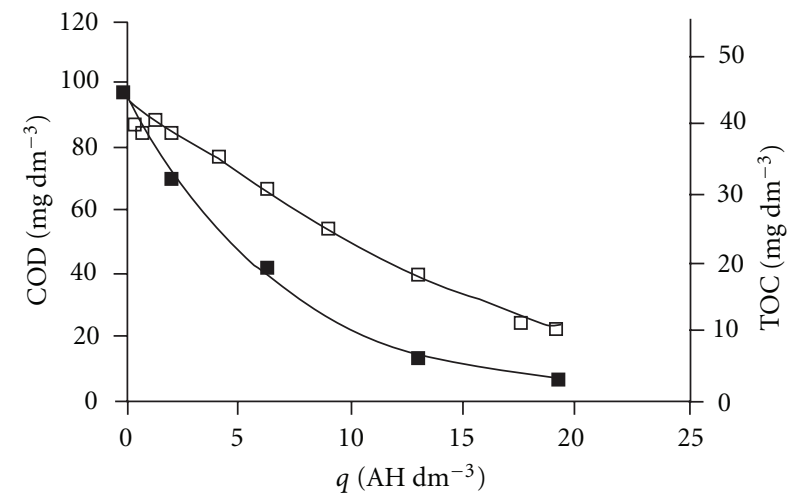

(a)

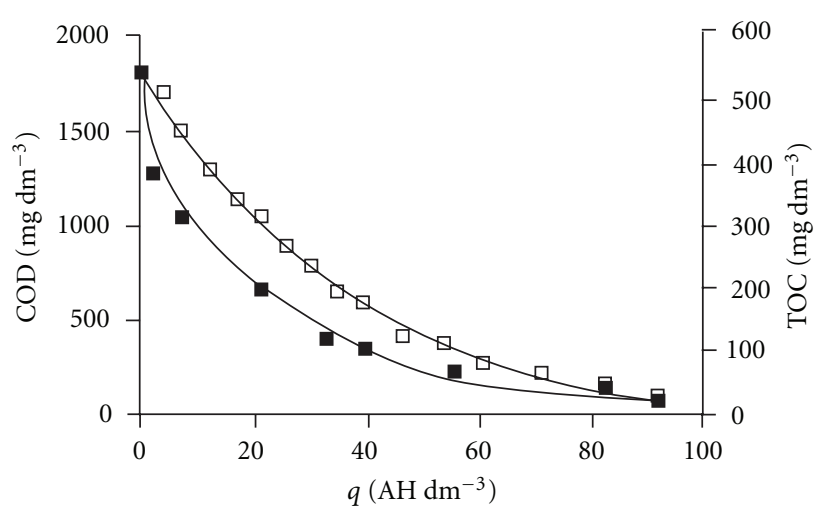

(b)

FIgure 3: Changes in the COD $(\mathbf{\square})$ and in the TOC $(\square)$ with the current charge passed during electrolyses of EBT-polluted synthetic wastes. Operation conditions: current density, $300 \mathrm{~A} \cdot \mathrm{m}^{-2} ; \mathrm{T}=25^{\circ} \mathrm{C}$. Waste composition: sodium sulfate $\mathrm{Na}_{2} \mathrm{SO}_{4}, 5000 \mathrm{mg} \cdot \mathrm{dm}^{-3} ; \mathrm{natural} \mathrm{pH}$. $\mathrm{COD}_{0}$ : (a) 100 and (b) $1813 \mathrm{mg} \cdot \mathrm{dm}^{-3} \mathrm{O}^{2}[20]$.

removing $\mathrm{MB}$. The study was carried out on $\mathrm{COD}$ and color removal efficiencies as a function of time, for each type of electrochemical processes. Figure 4 shows the comparison of COD abatement and color removal for both processes (direct and indirect electrolysis). As can be observed, the graph shows interesting results, because indirect electrolysis facilitates faster mineralization and decolorization of the solution. The authors attributed this behavior to the strong bleaching properties of active chlorine, and the efficiency of direct electrolysis is limited by the mass transport of pollutants to the anode surface in solutions containing low concentrations of organics.

Based on the literature results reported by Panizza and Cerisola, the ability to remove organic pollutants, like azo dyes, is more evident when diamond electrodes are used. These assertions were confirmed when the electrocatalytic properties of different materials are compared; the anodic oxidation of methyl red was studied comparing the electrocatalytic properties of $\mathrm{Ti}-\mathrm{Ru}-\mathrm{Sn}$ ternary oxide, platinum, lead dioxide, and boron-doped diamond anodes. The results of the study demonstrated a different reactivity of electrogenerated hydroxyl radicals for each electrode, limiting the removal efficiency of methyl red removal and COD abatement.

The authors speculate that on BDD, which is well known to have weak adsorption properties due to its inert surface, hydroxyl radicals are very weakly adsorbed and consequently they are very reactive toward organics oxidation. On the contrary, lead dioxide is hydrated and hydroxyl radicals are expected to be more strongly adsorbed on its surface and consequently less reactive. For these reasons, $\mathrm{TiRuSnO}_{2}$ and $\mathrm{Pt}$ anodes, which are good electrocatalysts for the oxygen evolution reaction due to their low oxygen evolution overpotential, showed poor elimination efficiencies. Contrarily $\mathrm{PbO}_{2}$ and $\mathrm{BDD}$ anodes, with high oxygen evolution overpotential making those poor electrocatalysts for the oxygen evolution reaction, had higher rates of COD and color removals. The same behavior was observed when Panizza and Cerisola [23] compared the electrocatalytic

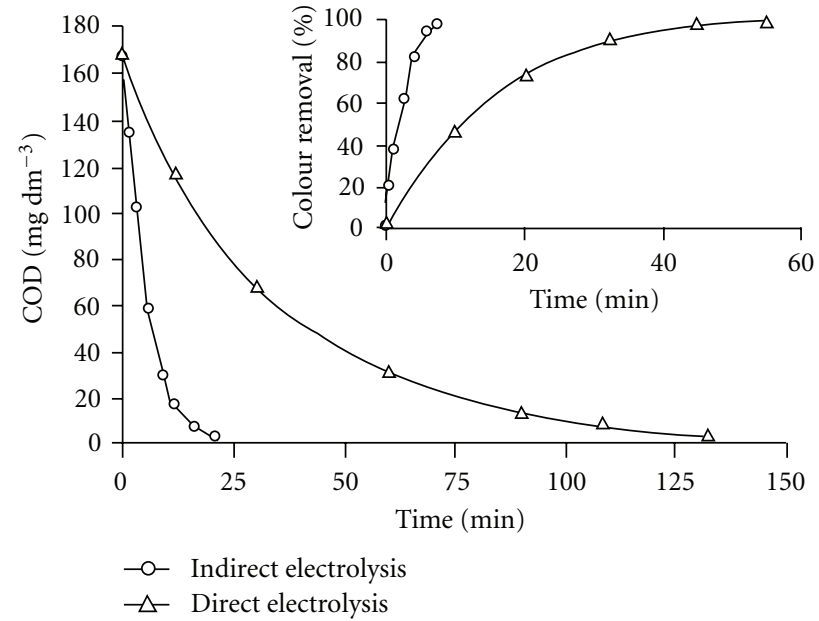

FIGURE 4: Comparison of the COD evolution and colour removal (inset) during the direct and mediated electrolysis of the methylene blue. Indirect electrolysis: $\mathrm{Cl}^{-}$concentration $=1.2 \mathrm{~g} \mathrm{dm}^{-3} ; i=$ $60 \mathrm{~mA} \mathrm{~cm}{ }^{-2}$; flow rate: $180 \mathrm{dm}^{3} \mathrm{~h}^{-1} ; \mathrm{T}=40^{\circ} \mathrm{C}$. Direct electrolysis: $i=20 \mathrm{~mA} \mathrm{~cm}^{-2}$; flow rate: $180 \mathrm{dm}^{3} \mathrm{~h}^{-1}, T=40^{\circ} \mathrm{C}[22]$.

properties between lead dioxide $\left(\mathrm{PbO}_{2}\right)$ and $\mathrm{BDD}$ anodes for the electrochemical incineration of methyl red, using an electrolytic flow cell with parallel plate electrodes. Results indicated that, for all of the applied currents, the COD decreased to zero, after 8 hours of treatment using a $\mathrm{PbO}_{2}$ anode. Whereas, the COD decreased to zero with all applied currents after $4 \mathrm{~h}$ of treatment using a BDD anode, resulting in complete mineralization of the dye by means of the electrogenerated ${ }^{\bullet} \mathrm{OH}$ radicals. The influence of the current density on the COD and CE during the electrochemical oxidation of methyl red at the BDD anode is shown in Figure 5.

The influence of different operational conditions (such as initial dye concentration, $\mathrm{Na}_{2} \mathrm{SO}_{4}$ concentration as supporting electrolyte, current density, flow rate, and initial $\mathrm{pH}$ ) during azo dye degradation has received great attention by 


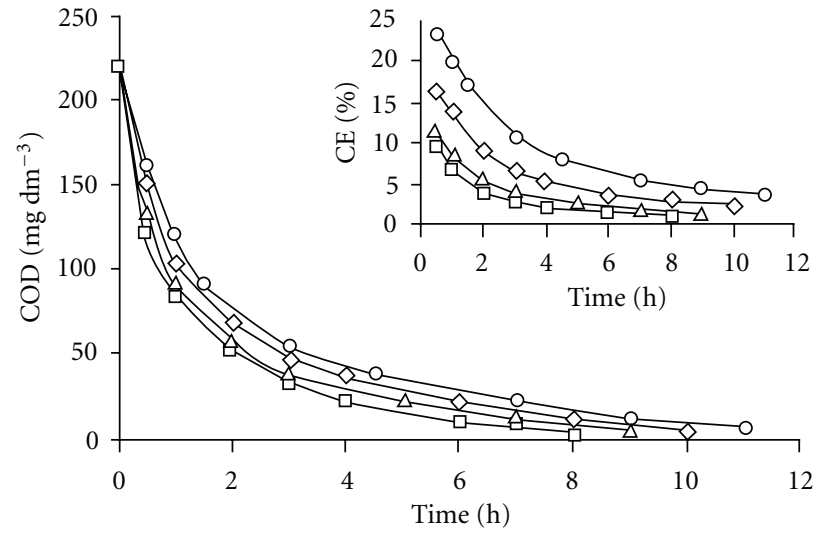

(a)

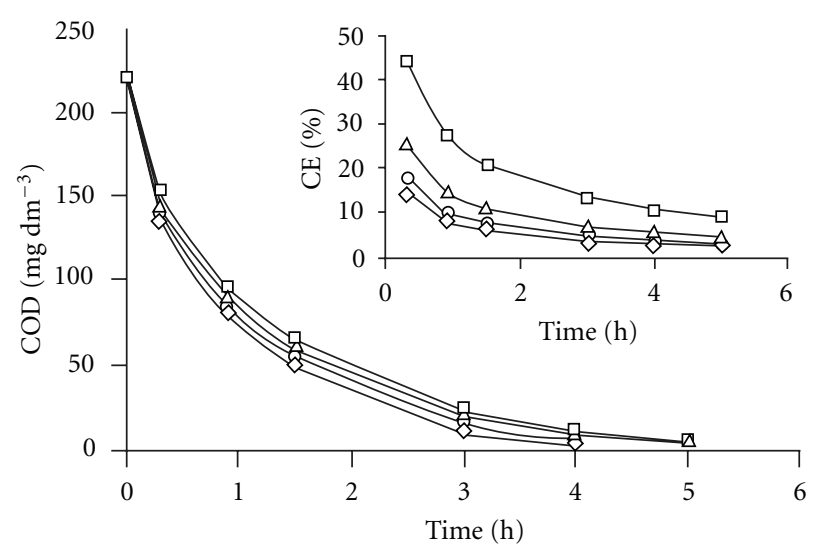

(b)

FIGURE 5: Influence of the applied current on the evolution of the COD and current efficiency (inset) as a function of time during the electrolysis of methyl red on the (a) $\mathrm{PbO}_{2}$ and (b) BDD anodes, respectively. Flow rate $=180 \mathrm{dm}^{3} \mathrm{~h}^{-1}$; $\mathrm{pH}=3$; applied current $=(\bigcirc) 0.5$, ( $\left.\diamond\right)$ $1,(\triangle) 1.5,(\square) 2 \mathrm{~A}[23]$.

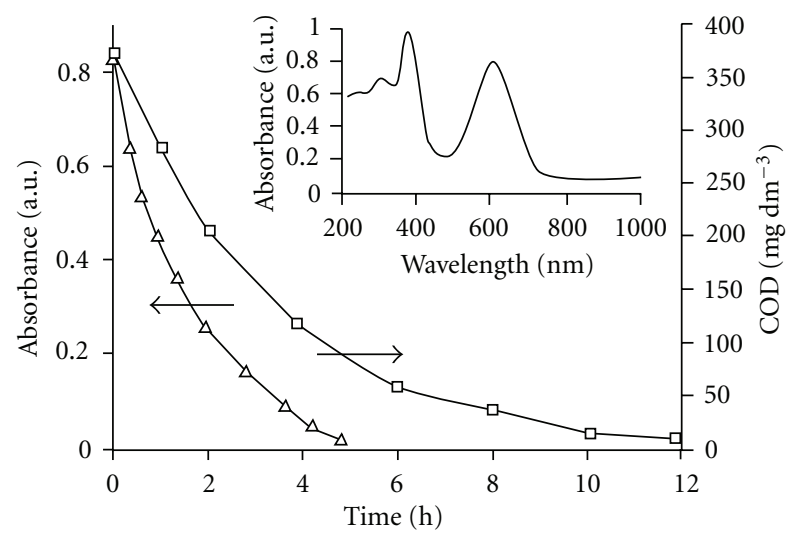

Figure 6: Trend of absorbance band at $594 \mathrm{~nm}(\triangle)$ and COD $(\square)$ during the anodic oxidation solution of acid blue 22 at a $0.3 \mathrm{mM}$ concentration on the BDD electrode at $i=20 \mathrm{~mA} \mathrm{~cm}^{-2}$, flow rate $=$ $300 \mathrm{dm}^{3} \mathrm{~h}^{-1}, \mathrm{~T}=25^{\circ} \mathrm{C}$. UV spectrum of the acid blue 22 is shown in the inset [24].

several authors (Panizza and Cerisola [24], Bensalah et al. [25], Koparal et al. [26], Carvalho et al. [27], and Saez et al. [28]).

For example, Panizza and Cerisola evaluated the electrochemical oxidation of synthetic wastewater containing acid blue 22 dye using a BDD electrode [24]. This study investigated the influence of certain variables such as current density, dye concentration flow rate, and temperature on the abatement of COD and color. Figure 6 presents an interesting comparison between color removal and COD abatement for $0.3 \mathrm{mM}$ of acid blue 22 by applying $20 \mathrm{~mA} \mathrm{~cm}^{-2}$ current density. Complete solution decolorisation after about $4 \mathrm{~h}$ of electrolysis was achieved, while $7 \mathrm{~h}$ was necessary to complete COD elimination, indicating that acid blue 22 was oxidized initially to colorless intermediates and then to carbon dioxide. Figure 7 compares energy consumption $\left(\mathrm{kWh} \mathrm{m}^{-3}\right)$ for COD and color removal of acid blue 22 at a $0.3 \mathrm{mM}$ concentration during electrochemical oxidation

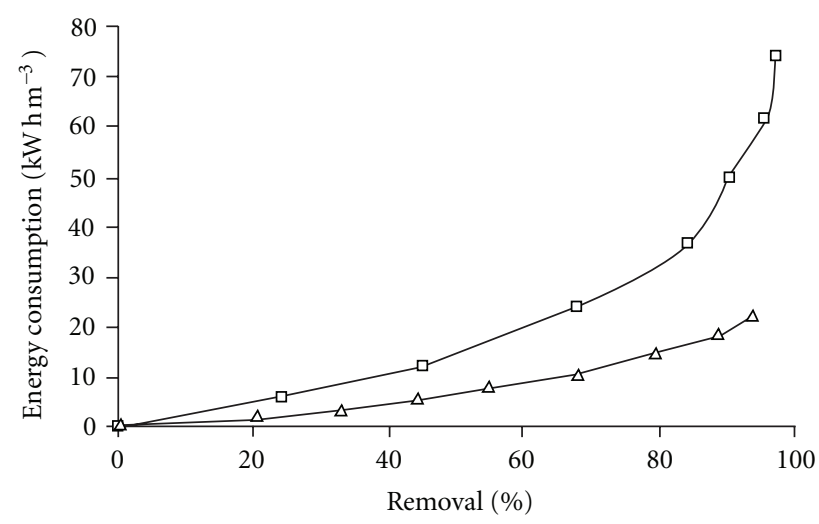

FIGURE 7: Evolution of the specific energy consumption against the removal of COD $(\square)$ and color $(\triangle)$ during the anodic oxidation of acid blue 22 . Acid blue 22 concentration: $0.3 \mathrm{mmol}$; current density $20 \mathrm{~mA} \mathrm{~cm}^{-2}$; flow rate $300 \mathrm{dm}^{3} \mathrm{~h}^{-1} ; T=25^{\circ} \mathrm{C}$ [24].

using a BDD anode. The result is very important from an economic point of view because the energy consumption increased almost linearly with color removalbut had a sharp increase with COD removal. On the other hand, Bensalah et al. [25] investigated the treatment of synthetic wastewaters containing Alphazurine A (AZA) by anodic oxidation using BDD anodes, monitoring COD and color removal under different operational conditions. According to the experimental results obtained in this work, the electrochemical oxidation process is suitable for removing COD and decolorizing wastewaters containing AZA dye, due to the production of hydroxyl radicals and other oxidants on the anode surface. Whereas, the energy requirements for removing $95 \%$ of initial COD during galvanostatic electrolyses of AZA synthetic solutions depends mainly on the applied current density, temperature and agitation rate; it passes from $57 \mathrm{kWh}$ at $30 \mathrm{~mA} \mathrm{~cm}^{-2}$ to $138 \mathrm{kWh}$ at $90 \mathrm{~mA} \mathrm{~cm}^{-2}$ per $\mathrm{kg}$ COD removed; from $102 \mathrm{kWh}$ at $25^{\circ} \mathrm{C}$ to $89 \mathrm{kWh}$ at 
TABLE 1: Percentage of color removal and COD decay obtained for the electrochemical oxidation treatment with BDD anodes of selected synthetic dyes solutions under optimized conditions at ambient temperature or $25^{\circ} \mathrm{C}$.

\begin{tabular}{|c|c|c|c|c|c|c|}
\hline Dye & Solution & Electrolytic system & $j^{\mathrm{a}} / \mathrm{mA} \mathrm{cm}^{-2}$ & $\begin{array}{c}\text { Color } \\
\text { removal } / \% \\
\end{array}$ & COD decay $/ \%$ & Ref. \\
\hline $\begin{array}{l}\mathrm{Si} / \mathrm{BDD} \\
3,4,5- \\
\text { trihydroxybenzoic } \\
\text { acid) }\end{array}$ & $\begin{array}{l}1000 \mathrm{mg} \mathrm{dm} \\
\mathrm{HClO}_{4}\end{array}$ & $\begin{array}{l}\text { A one-compartment electrolytic } \\
\text { flow cell with parallel plate } \\
\text { electrodes. }\end{array}$ & $20-60$ & 100 & 100 & {$[43]$} \\
\hline $\begin{array}{l}\text { Remazol Brilliant } \\
\text { Blue }\end{array}$ & $\begin{array}{l}50 \mathrm{mg} \mathrm{dm}^{-3} \mathrm{RBBR} \\
0.05 \mathrm{M} \mathrm{Na}_{2} \mathrm{SO}_{4} \text { and } \\
0.01 \mathrm{M} \mathrm{NaCl} \text { with an } \\
\text { initial pH of } 5.8 \text { and } \\
\text { conductivity } \\
8.5 \mathrm{~ms} \mathrm{~cm}^{-1}\end{array}$ & $\begin{array}{l}\text { Batch mode in a } 100-\mathrm{mL} \\
\text { single-compartment cell with a } \\
\text { boron-doped diamond anode of } \\
\text { geometric area } 5 \mathrm{~cm}^{2} .\end{array}$ & $20-40$ & 99 & 98 & {$[29]$} \\
\hline Acid Yellow 1 & $\begin{array}{l}1000 \mathrm{mg} \mathrm{dm}^{-3} \text { in } \\
0.5 \mathrm{M} \mathrm{HClO}_{4}\end{array}$ & $\begin{array}{l}\text { A one-compartment electrolytic } \\
\text { flow cell with a BDD of } 50 \mathrm{~cm}^{2} \text {. }\end{array}$ & $0.5-1.5^{b}$ & 100 & 100 & {$[30]$} \\
\hline O-toluidine & $1 \times 10^{-4}-1 \times 10^{-3} \mathrm{M}^{\mathrm{c}}$ & $\begin{array}{l}\text { A two compartments } \\
\text { Thermostated cell under } \\
\text { different current densities, } \\
\text { temperatures, and COT } \\
\text { concentration. }\end{array}$ & $20-100$ & $-^{\mathrm{d}}$ & $70-90$ & {$[33]$} \\
\hline Basic Blue 3 & $1000 \mathrm{mg} \mathrm{dm}^{-3}$ & $\begin{array}{l}\text { thermojacketed BTT reactor was } \\
\text { used with BDD Raschig's rings. }\end{array}$ & $0.5-0.875$ & 99 & 87 & {$[34]$} \\
\hline Crystal violet & $33-600 \mathrm{mg} \mathrm{dm}^{-3}$ & $\begin{array}{l}\text { In a } 150 \mathrm{~mL} \text {, one-compartment } \\
\text { electrolytic cell with a BDD of } \\
4 \mathrm{~cm}^{2} .\end{array}$ & $2.5-15$ & 100 & $80-95$ & {$[44]$} \\
\hline Acid Black 210 & $500 \mathrm{mg} \mathrm{dm}^{-3}$ & $\begin{array}{l}\text { In an one-compartment } \\
\text { filter-press flow cell. }\end{array}$ & $25-100$ & 100 & $80-97$ & {$[35]$} \\
\hline $\begin{array}{l}N b / B D D \\
\text { Orange II }\end{array}$ & $\begin{array}{l}50 \mathrm{mg} \mathrm{dm}^{-3} \text { in the } \\
\text { presence of different } \\
\text { supporting } \\
\text { electrolytes, } 200 \mathrm{~mL} \\
\text { in each run }\end{array}$ & $\begin{array}{l}\text { Batch recirculation } \\
\text { reactorcontaining } \\
\text { one-compartment cell equipped } \\
\text { with boron-doped diamond } \\
\text { anode and Pt cathode. }\end{array}$ & $1.29-7.68$ & $80-98$ & $80-95$ & {$[31]$} \\
\hline $\begin{array}{l}\text { Ti/BDD } \\
\text { Alizarin Red S }\end{array}$ & $0.278 \mathrm{mM}^{\mathrm{c}}$ & $\begin{array}{l}\text { Electrolytic cell with a single } \\
\text { compartment without } \\
\text { diaphragm with Ti/BDD } \\
\left(1.5 \mathrm{~cm}^{2}\right) \text { anode and } \\
\mathrm{Ti}^{2} \mathrm{RuO}_{2}-\mathrm{TiO}_{2}-\mathrm{SnO}_{2}\left(9 \mathrm{~cm}^{2}\right) \\
\text { cathode. }\end{array}$ & 40 & 100 & 100 & {$[41]$} \\
\hline
\end{tabular}

${ }^{\mathrm{a}}$ Applied current density, ${ }^{\mathrm{b}}$ potential, ${ }^{\mathrm{c}}$ molar concentration, ${ }^{\mathrm{d}}$ not determined.

$60^{\circ} \mathrm{C}$ and from $141 \mathrm{kWh}$ at $100 \mathrm{rpm}$ to $29 \mathrm{kWh}$ at $400 \mathrm{rpm}$. Based on results reported by several authors (Panizza and Cerisola [24], Bensalah et al. [25], Koparal et al. [26], Carvalho et al. [27] and Saez et al. [28]), the electrochemical technique is economically suitable for waste pre-treatment to remove color. However, although complete COD removal is technically feasible, its high-energy cost makes this technique unsuitable for a refining process.

Nevertheless, the application of electrochemical technologies for decolorization and degradation of azo dyes has been investigated and reported by several scientific groups, as recently reviewed in details by Martínez-Huitle and Brillas [16]. However, since this review was published, new results have been published and more statements have been established. The destruction by EO with BDD of dyes such as Remazol Brilliant Blue Reactive [29], Acid Yellow 1 [30], Orange II [31], Reactive Orange 16
[32], O-Toluidine [33], Basic Blue 3 [34], acid black 210 [35], Trichloroethylene [36], methylene blue [37], 3-amino4-hydroxy-5-nitrobenzenesulfonic acid (A1), 5-amino-2methoxybenzenesulfonic acid (A2), 2,4-dihydroxyaniline hydrochloride (A3) and benzene-1,4-diamine (A4) [38], methyl orange [39], Reactive brilliant red X-3B [40], Alizarin Red S [41], Aniline (AN) and Ortanilic (OA), Metanilic (MA) and Sulfanilic (SA) acids [42], Gallic acid [43] and Crystal Violet [44], has been studied. In these studies the influence of $\mathrm{pH}$, dye content, temperature, supporting electrolyte, cathode material, current density, and anode potential was investigated for optimizing degradation conditions. Many of these authors also estimated the color removal, current efficiency and decay in COD and/or TOC, which mainly depended on the above parameters. Data are collected in Table 1, and the most relevant papers will be discussed and commented below. 
The electrochemical oxidation of aniline (AN) and ortanilic (OA), metanilic (MA), and sulfanilic (SA) acids (dyes precursors) was studied by Santos et al. [42] using a BDD electrode. Model solutions of the different amines with concentrations of $200 \mathrm{mg} \mathrm{L}^{-1}$ in $0.035 \mathrm{M} \mathrm{Na}_{2} \mathrm{SO}_{4}$ were oxidized using a batch cell by applying 200 and $300 \mathrm{Am}^{-2}$. Results showed a good elimination of the persistent pollutants, with COD and TOC removals always higher: AN: $91 \%$ and $90 \%$, OA: $75 \%$ and $82 \%$, MA: $88 \%$ and $87 \%$, and SA: $85 \%$ and $79 \%$ (for 200 and $300 \mathrm{~A} \mathrm{~m}^{-2}$, resp.). The combustion efficiencies, calculated for the first hour of the runs, for the $300 \mathrm{~A} \mathrm{~m}^{-2}$ assays, were the following: $\mathrm{AN}: 0.93$, OA: 0.28 , MA: 0.82 , and SA: 0.83 , indicating the efficiency of the BDD anode for removing these dyes precursors. For all the amines studied, after $6 \mathrm{~h}$ degradation, only oxalic and maleic acids were identified by HPLC. Additionally, analysis performed to the content of different forms of nitrogen in solution led to the conclusion that, in the case of the sulfonated amines, the amino group was mainly eliminated in the form of ammonia, since AMN content increases while TKN decreases.

Another study evaluated the electrochemical oxidation of several dyes precursors [38], such as 3-amino-4-hydroxy5-nitrobenzenesulfonic acid (A1), 5-amino-2-methoxybenzenesulfonic acid (A2), 2,4-dihydroxyaniline hydrochloride (A3), and benzene-1,4-diamine (A4), using a BDD electrode as the anode. Tests were run at room temperature with model solutions of the different amines at concentrations of $200 \mathrm{ppm}$, using $0.035 \mathrm{M} \mathrm{Na}_{2} \mathrm{SO}_{4}$ aqueous solutions as electrolytes, in a batch cell with recirculation at different current densities (200 and $300 \mathrm{Am}^{-2}$ ).

From the results obtained by these authors, the anodic oxidation of four dyes precursors, using a BDD anode, showed high COD and TOC removals (see Figure 8). For the assays run with the first two compounds, after $4 \mathrm{~h}$, no amine was detected by HPLC. For the tests with the other two compounds, small amounts of the amines were still present at the end of the assay, and higher combustion efficiencies were observed. Apparently, a high initial amine removal rate leads to a lower degree of mineralization. Additionally, the substituent has an effect on the rate of degradation mainly due to its contribution to the molar volume, since diffusivity and, consequently, mass transfer coefficient decrease with its increase. The anodic oxidation of 2,4-dihydroxyaniline hydrochloride and benzene-1,4-diamine was the only instance where hydroquinone and maleic acid were identified as metabolites, after a $6 \mathrm{~h}$ run. These particular oxidations also produced higher combustion efficiencies. It seems that the early formation of oxalic acid reduces the ability to obtain mineralization. On the other hand, the formation of other intermediates, like hydroquinone, may lead to an easier complete combustion of the organic matter. Analysis performed to different forms of nitrogen content led to the conclusion that the amino group is mainly eliminated in the form of ammonia, since AN content increases while TKN decreases during the anodic oxidation.

Zhou and Särkkä [39] compared the electrochemical degradation of methyl orange on the mixed metal oxide
(MMO) and BDD electrodes. The effect of several parameters such as current density, $\mathrm{pH}$, electrolyte types, and initial dye concentration were investigated in terms of decolorization. COD and TOC removals, as well as energy consumption, were estimated. The degradation on two electrodes presented different trends in operative parameters. High current density enhanced the decolorization on both electrodes, but the promotion on MMO was not as significant as that on the BDD electrode, which led to a sharp increase of specific energy consumption, as shown in Figure 9. The decolorization of MMO performed better at acidic conditions for two electrodes, but the dependence of $\mathrm{pH}$ on BDD was not as obvious as that on MMO electrodes.

The presence of $\mathrm{NaCl}$ favored the indirect oxidation of active chlorines on MMO electrodes, which greatly improved the decolorization rate. High initial concentration enhanced general current efficiency (GCE) although the COD and TOC removal efficiency was decreased. The GCE on BDD was much higher than that on $\mathrm{MMO}$, indicating that it was much more efficient. The BDD electrode yielded high combustion efficiency, while on MMO is greatly improved in the presence of $\mathrm{NaCl}$.

Due to the applicability of mediated oxidation using DSA or BDD anodes, other groups have focused attention on this electrochemical process, evaluating different operating conditions. For example, the electrochemical degradation of chloride-mediated and chloride-free dye wastewaters (a synthetic solution containing high concentration methylene blue (MB), with $1000 \mathrm{mg} \mathrm{L}^{-1}$ ), was investigated by $\mathrm{Wu}$ and coworkers [37]. In chloride-free wastewater, the electrochemical degradation efficiency of dye on BDD electrode was much higher than that on DSA, with a COD removal of $100 \%$ and $26 \%$ for BDD and DSA, respectively. In chloridemediated dye wastewater, COD removal was faster than that in chloride-free wastewater on both BDD and DSA electrodes with COD removal efficiencies higher than $95 \%$, whereas the rate of COD removal on DSA was faster than that on BDD electrode. The investigation indicated that DSA is more suitable than BDD electrode in degradation of dye wastewaters containing chloride in terms of energy and time saving. However, for chloride-free dye wastewaters, BDD electrode is more appropriate, in regards to environmental protection, because of its ability to achieve complete mineralization. These assumptions are confirmed by the results reported in Figure 10.

As shown by several authors [16] and Wu et al. [37], the high chlorine evolution potential in $\mathrm{Cl}^{-}$-mediated wastewater may cause difficulty in the formation of active chlorine from wastewater and decrease the rate of electrochemical degradation of organic compounds, leading to a slower electrochemical degradation process on BDD. The lower chlorine evolution potential of $1.0 \mathrm{~V}$ on the DSA probably makes the formation of active chlorine on DSA surface much easier, so that the oxidation rate of MB on DSA is much higher than that on BDD due to the strong oxidative property of active chlorine. As the electrolysis takes place, the concentration of chloride in electrolyte decreases gradually, and the amount of active chlorine on the electrode surface 

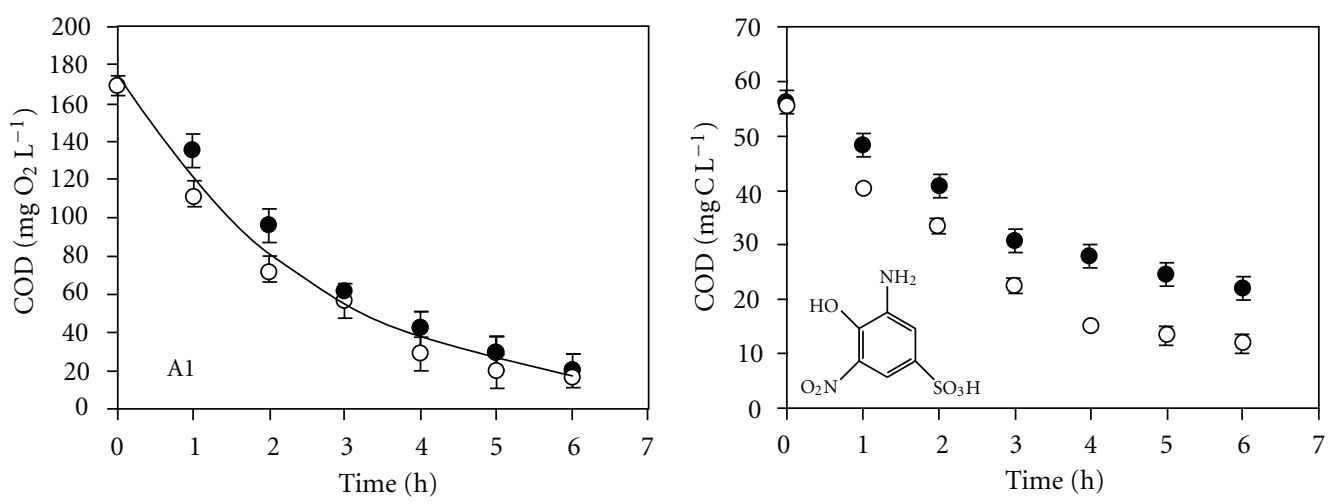

$\begin{array}{ll}- & 20 \mathrm{~mA} \mathrm{~cm}^{-2} \\ \bigcirc & 30 \mathrm{mAcm}^{-2} \\ & \text { COD } / \text { COD } 0=\exp (-0.379 t) \\ & r^{2}=0.962\end{array}$

- $20 \mathrm{~mA} \mathrm{~cm}^{-2}$

○ $30 \mathrm{mAcm}^{-2}$

(a)

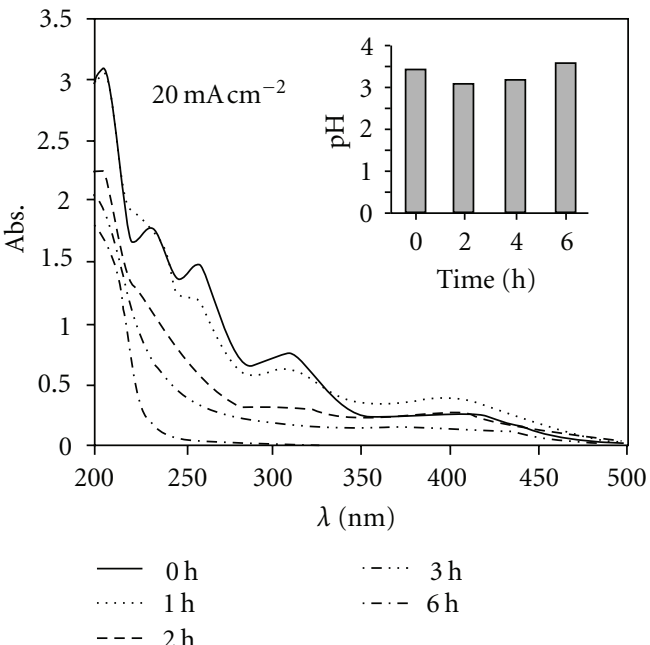

(c)

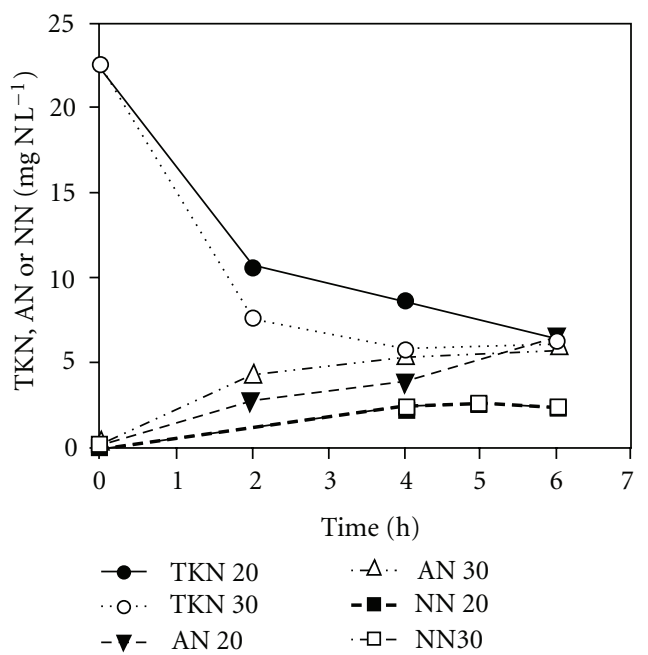

(e) (b)

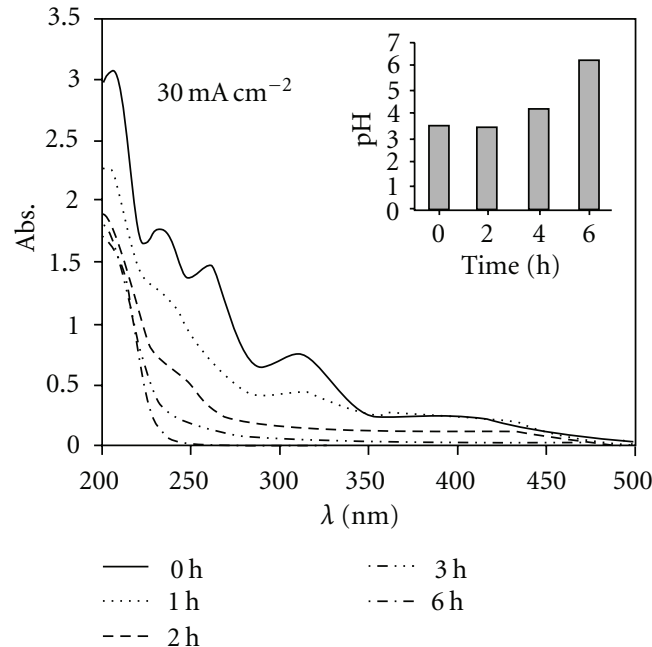

(d)

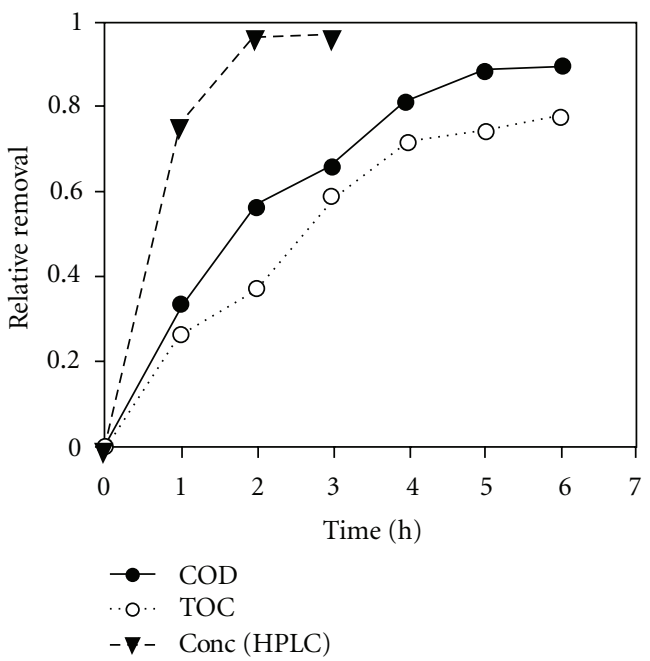

(f)

FIGURE 8: Variations of COD (a), TOC (b), absorbance and pH (c, d), TKN, AN and NN (e) and relative removals of COD, TOC and concentration (f) versus. time observed during the degradation assays of the amine $\mathrm{Al}$, with an initial concentration of $200 \mathrm{mg} \mathrm{L}^{-1}$, performed with a BDD anode $\left(8 \mathrm{~cm}^{2}\right)$. Cathode: stainless steel $\left(8 \mathrm{~cm}^{2}\right)$; current density: 20 and $30 \mathrm{~mA} \mathrm{~cm}^{-2}$; electrolyte $0.035 \mathrm{M} \mathrm{Na}_{2} \mathrm{SO}_{4}$ aqueous solution [38]. 


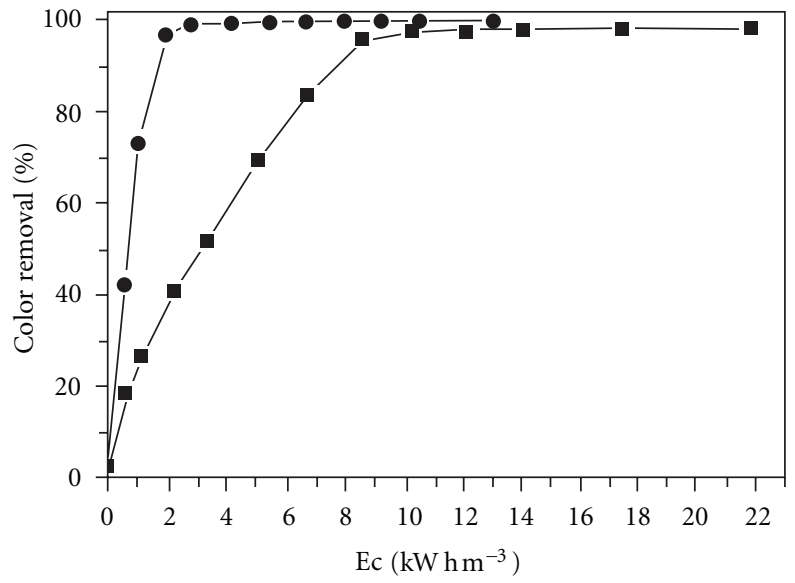

(a)

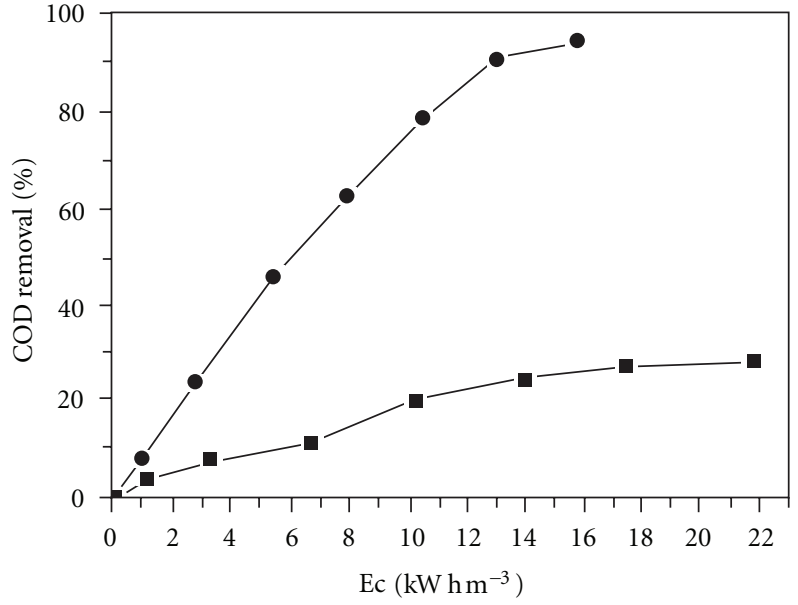

(b)

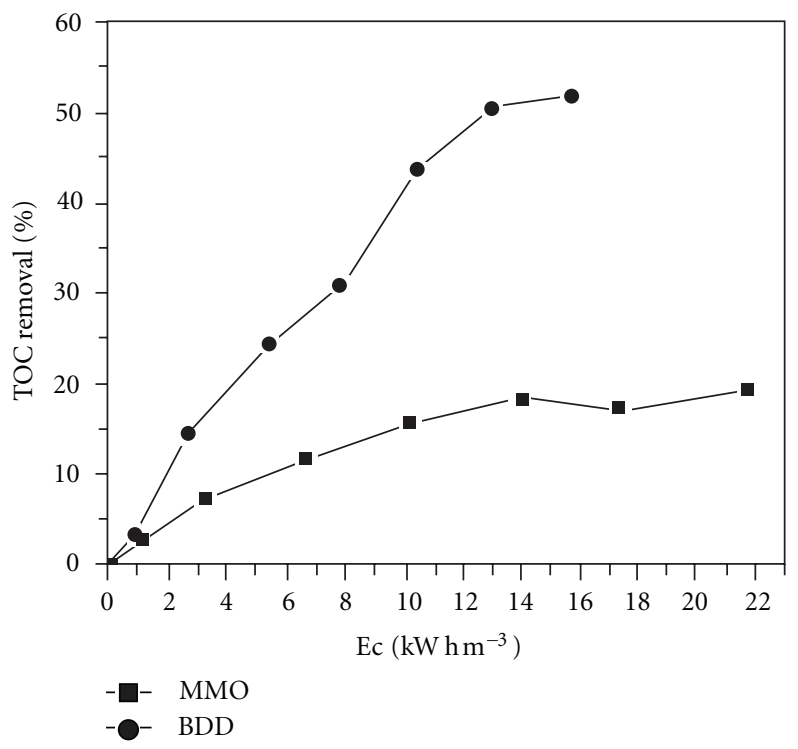

(c)

Figure 9: The removal of color, $\mathrm{COD}$, and TOC on two electrodes. Conditions: electrolyte: $\mathrm{Na}_{2} \mathrm{SO}_{4} 0.1 \mathrm{M}+\mathrm{NaCl} 0.05 \mathrm{M} ; \mathrm{pH} 3 ; \mathrm{MO}$ $200 \mathrm{mgL}^{-1}$; current density: $50 \mathrm{mAcm}^{-2}$. Reprinted with permission of Separation and Purification Technology [39].

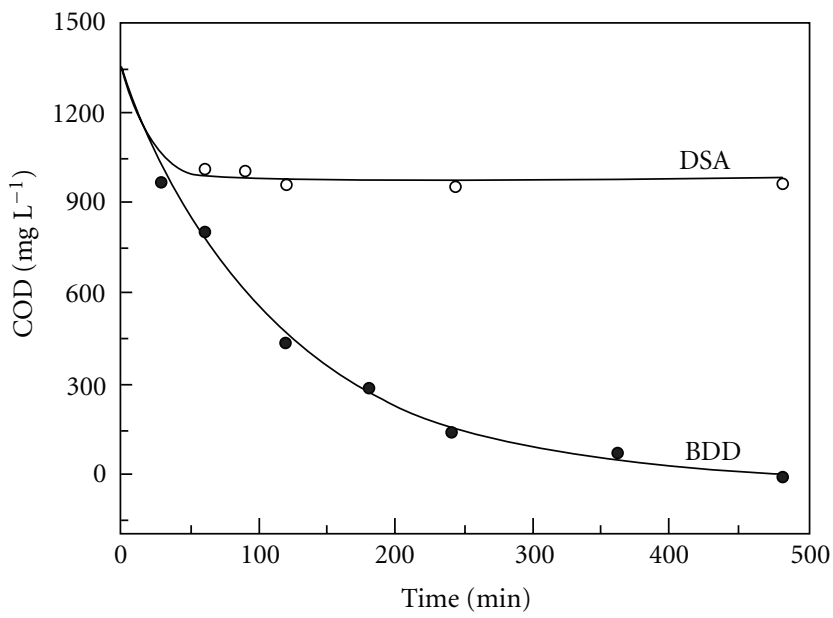

(a)

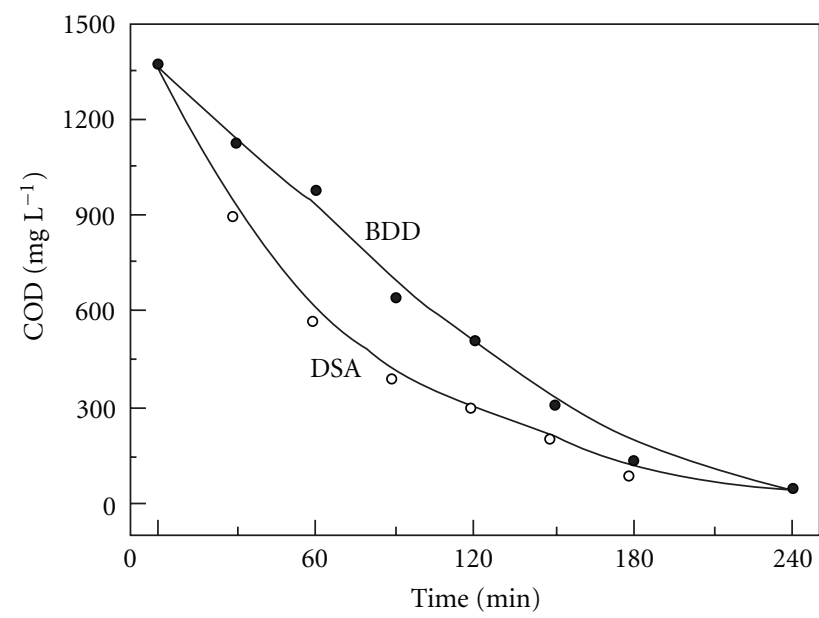

(b)

FIGURE 10: COD (a) in MB degradation in chloride-free wastewater and COD (b) in MB degradation in chloride-mediated wastewater [37]. 
decreases, so that the rate of electrochemical decontamination of wastewater is lowered. However, this electrochemical treatment of chloride-containing wastewater will introduce strong toxic halogen compounds and requires a second step to remove this chlorinated organic compound (e.g., by adsorption on activated carbon, coupled/integrated methods [45], or emerging technologies [16]).

Therefore, new electrochemical processes are being studied. For example, photocatalysis on nanosized $\mathrm{TiO}_{2}$ and electrocatalysis on BDD electrode, two advanced oxidation processes (AOPs) in the field of wastewater treatment, were combined into one batch reactor by Zhang and coworkers [40]. Reactive brilliant red X-3B dye was used as a model compound to study the combinatory effect between photocatalysis and electrocatalysis. The aim of this study was to confirm that the oxidants produced on BDD anodes such as hydrogen peroxide, ozone, and peroxodisulfate could raise the quantum efficiency of photocatalytic processes. Initially, the performances of the separate processes in the elimination of $\mathrm{X}-3 \mathrm{~B}$ were compared and different reaction systems of the same size were employed to study the performance in $\mathrm{X}-3 \mathrm{~B}$ decolorization, listed as (1) BDD alone; (2) BDD with UV light, without $\mathrm{TiO}_{2}$; (3) $\mathrm{TiO}_{2}$ photocatalysis with UV light; (4) $\mathrm{BDD}+\mathrm{UV}+\mathrm{TiO}_{2}$; (5) $\mathrm{BDD}+\mathrm{UV}+\mathrm{TiO}_{2}+$ aeration. The air rate was set to $5.0 \mathrm{~L} / \mathrm{h}$ by a small magnetic air pump.

The experimental conditions were set as follows: initial concentration of $\mathrm{X}-3 \mathrm{~B}\left(\mathrm{C}_{0}\right) 50 \mathrm{mg} / \mathrm{L}$; current density $25.2 \mathrm{~mA} / \mathrm{cm}^{2} ; \mathrm{pH} 2.72$ (adjusted with $1.0 \mathrm{M} \mathrm{H}_{2} \mathrm{SO}_{4}$ ). The time for removing color completely was studied for each reaction system, and the results were illustrated in Figures 11(a) and 11(b). It can be deduced that photocatalysis coupled with electrocatalysis in one reactor will degrade pollutants faster than either process alone. The results obtained show some interesting phenomena, commonly called synergistic effect. Both $\mathrm{BDD}$ electrode and $\mathrm{TiO}_{2}$ film produces ${ }^{\circ} \mathrm{OH}$ on their surfaces, and a portion of them may react directly with $\mathrm{X}-3 \mathrm{~B}$. As have been well established by the literature, oxidation of pollutants at the BDD anode occur under mass transfer control mainly in a thin liquid film near the electrode surface, where the concentration of $\cdot \mathrm{OH}$ is very high. Similar phenomenon also exists in photocatalytic systems. But the adding of salts $\left(\mathrm{SO}_{4}{ }^{2-}\right)$ can trap part of these $\cdot \mathrm{OH}$ to form peroxides and diffuse into the whole solution to allow full contact with $\mathrm{X}-3 \mathrm{~B}$. Then $\bullet \mathrm{OH}$ are set "free" by activating these mixture of oxidants $\left(\mathrm{H}_{2} \mathrm{O}_{2}\right.$, $\mathrm{S}_{2} \mathrm{O}_{8}{ }^{2-}$ ) with UV light, thus promotes the performance as well as the generation of more $\cdot \mathrm{OH}$ on the surfaces of both BDD electrode and $\mathrm{TiO}_{2}$ film. These experimental results revealed the suitability of the combination of the two oxidation processes for accelerating the removal of dye pollutants from solution.

Other scientific groups are studying the preparation of new electrocatalytic materials with similar characteristics of BDD anodes in order to decrease the cost of treatment and increase removal efficiency. In this context, interesting results have been reported by Andrade and Tasso [46] who studied the performances of the $\mathrm{Ti}-\mathrm{Pt} / \beta-\mathrm{PbO}_{2}$ and $\mathrm{BDD}$ electrodes in the electrooxidation of simulated wastewaters containing $85 \mathrm{mg} \mathrm{L}^{-1}$ of the Reactive Orange 16 dye using a filter-press reactor. The electrolyses were carried out at the flow rate of $7 \mathrm{~L} \mathrm{~min}^{-1}$, at different current densities $\left(10-70 \mathrm{~mA} \mathrm{~cm}^{-2}\right)$, and in the absence or the presence of chloride ions (10-70 $\mathrm{mM} \mathrm{NaCl}$ ). In the absence of $\mathrm{NaCl}$, total decolorisation of the simulated dye wastewater was attained independently of the electrode used. However, according to the results reported by the authors, the performance of the BDD electrode was better than that of the $\mathrm{Ti}-\mathrm{Pt} / \beta$ $\mathrm{PbO} 2$ electrode; the total decolorizations were achieved by applying only $1.0 \mathrm{Ah} \mathrm{L}^{-1}$ and $2.0 \mathrm{Ah} \mathrm{L}^{-1}$, respectively. In the presence of $\mathrm{NaCl}$, with the electrogeneration of active chlorine, the times needed for total color removal were markedly decreased; the addition of $50 \mathrm{mM} \mathrm{Cl}^{-}$or $35 \mathrm{mM} \mathrm{Cl}^{-}$(for $\mathrm{Ti}-\mathrm{Pt} / \beta-\mathrm{PbO}_{2}$ or $\mathrm{BDD}$, resp.) to the supporting electrolyte led to a $90 \%$ decrease of these times (at $50 \mathrm{~mA} \mathrm{~cm}^{-2}$ ). On the other hand, total mineralization of the dye in the presence of $\mathrm{NaCl}$ was attained only when using the BDD electrode (for $1.0 \mathrm{Ah} \mathrm{L}^{-1}$ ); for the $\mathrm{Ti}-\mathrm{Pt} / \beta$ $\mathrm{PbO}_{2}$ electrode, a maximum mineralization of $85 \%$ was attained (for $2.0 \mathrm{Ah} \mathrm{L}^{-1}$ ). For total decolorization of the simulated dye wastewater, the energy consumption per unit mass of dye oxidized was only $4.4 \mathrm{kWh} \mathrm{kg}^{-1}$ or $1.9 \mathrm{kWh} \mathrm{kg}^{-1}$ using the $\mathrm{Ti}-\mathrm{Pt} / \beta-\mathrm{PbO}_{2}$ or $\mathrm{BDD}$ electrode, respectively. Clearly the BDD electrode proved to be the best anode for the electrooxidative degradation of the dye, either in the presence or the absence of chloride ions. In the absence of chloride, this high performance is due to the fact that the electrogenerated hydroxyl radicals are weakly adsorbed on the BDD because of its inertness; consequently, they are very reactive towards the dye oxidation. On the $\mathrm{Ti}-\mathrm{Pt} / \beta-\mathrm{PbO}_{2}$ surface, the hydroxyl radicals are more strongly adsorbed, thus being less reactive. Whereas, the addition of chloride to the simulated dye wastewater had a very marked effect on the dye degradation; the time needed for total decolorization of the dye decreased by $90 \%$. This increased performance is most probably related to the weak chlorohydroxyl adsorption strength on the BDD surface, as it is the case with the hydroxyl radical.

\subsection{Electrochemical Treatment of Real Wastewaters Polluted} with Dyes. Few papers have demonstrated that the use of a BDD thin film in EO provides total mineralization with high current efficiency of real textile wastewaters [16]. However, more studies have been published in the last three years.

Chatzisymeon et al. [47], using a titanium (grade II/VII) anode covered by a thin film of tantalum, platinum, and iridium alloy, attained 98\% decolorization within 10-15 min, regardless of the applied current. From their best data (use of $5 \mathrm{~A}$ for $10 \mathrm{~min}, 8 \mathrm{~L}$ of effluent), one infers that only $0.38 \mathrm{kC} \mathrm{L}^{-1}$ was used, which is much lower than the value used in our best case $\left(5.8 \mathrm{kC} \mathrm{L}^{-1}\right)$; however, they added $\mathrm{NaCl}$ to the effluent to have a minimum concentration of $10 \mathrm{~g} \mathrm{~L}^{-1}$ while we used only $1.5 \mathrm{~g} \mathrm{~L}^{-1}$.

Fytianos et al. [48] compared the use of two different anodes: platinized titanium $(\mathrm{Pt} / \mathrm{Ti})$ and $\mathrm{Nb} / \mathrm{BDD}$, in order to improve the electrochemical incineration of synthetic samples containing four reactive azo dyes and real wastewater. They compare their treatment through biochemical oxygen 


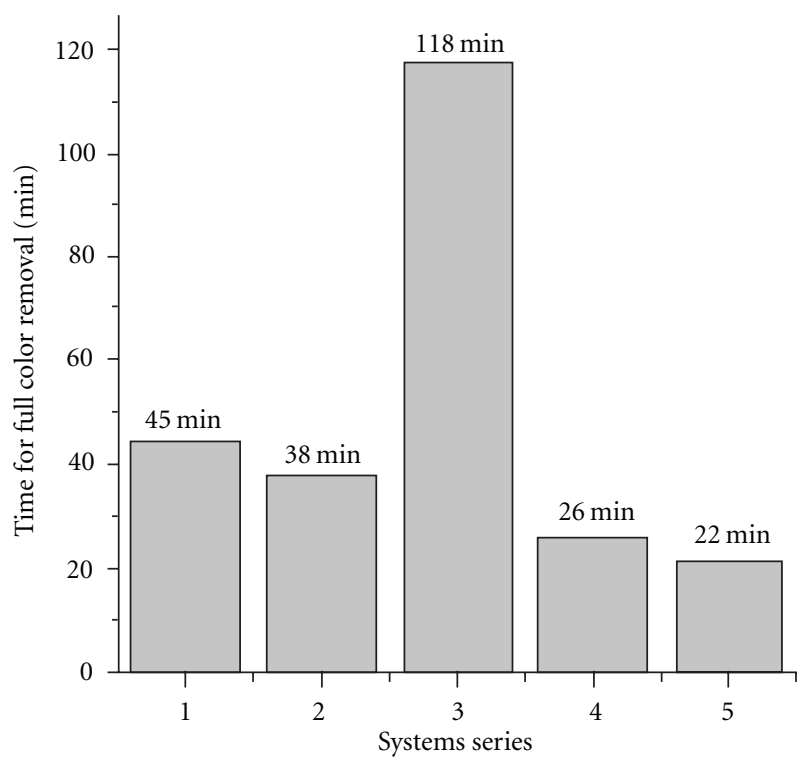

(a)

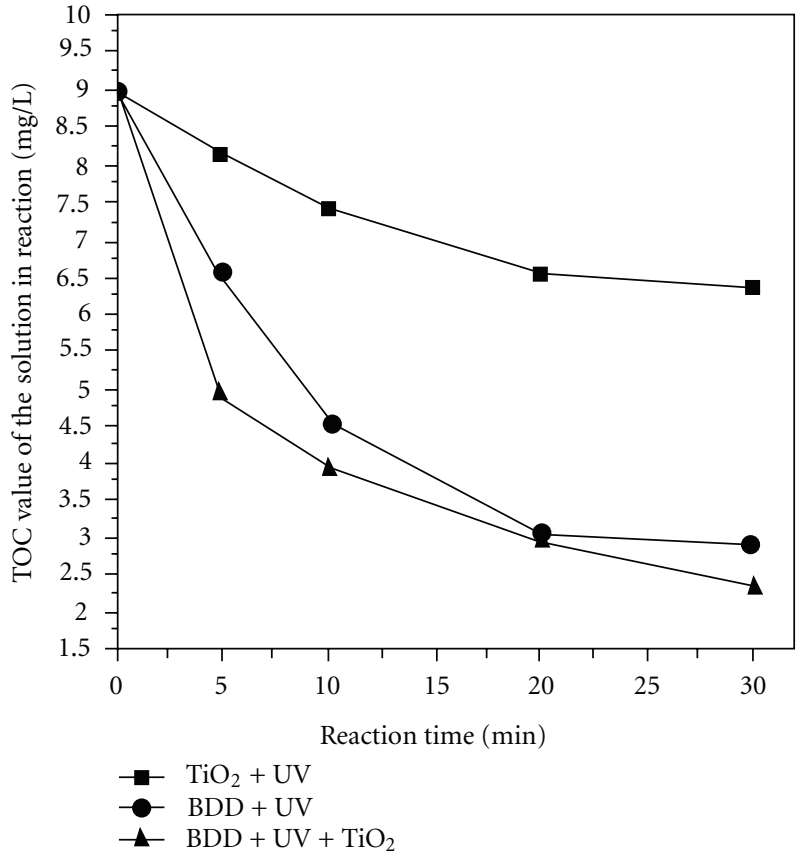

(b)

FIGURE 11: (a) Comparison on degradation performance of different reaction systems and (b) TOC decay with reference to electrolysis time for the mineralization of X-3B with three different systems $\left(C_{0}: 50 \mathrm{mg} / \mathrm{L}, I_{\mathrm{appl}}=25.2 \mathrm{~mA} / \mathrm{cm}^{2}, \mathrm{pH} 2.72\right)$ [40].

TABLe 2: Initial and final values of the most important environmental parameters of electrochemically treated wastewater under optimal conditions [48].

\begin{tabular}{|c|c|c|c|}
\hline \multirow[t]{2}{*}{$\begin{array}{l}\text { Environmental } \\
\text { parameter }\end{array}$} & \multirow{2}{*}{$\begin{array}{c}\text { Initial } \\
\text { wastewater }\end{array}$} & \multicolumn{2}{|c|}{$\begin{array}{l}\text { Electrochemically } \\
\text { treated wastewater }\end{array}$} \\
\hline & & $\mathrm{Pt} / \mathrm{Ti}$ & $\mathrm{Nb} / \mathrm{D}$ \\
\hline $\mathrm{pH}$ & 9 & 8 & 8 \\
\hline $\begin{array}{l}\text { \% Dye removal } \\
(436 \mathrm{~nm})\end{array}$ & - & 67.3 & 81.2 \\
\hline $\begin{array}{l}\text { \% Dye removal } \\
(526 \mathrm{~nm})\end{array}$ & - & 82.4 & 89.1 \\
\hline $\begin{array}{l}\text { \% Dye removal } \\
(620 \mathrm{~nm})\end{array}$ & - & 80.3 & 89.5 \\
\hline Chlorides (mg/L) & 224 & 174 & 112 \\
\hline $\begin{array}{l}\text { Hypochlorites } \\
(\mathrm{mg} / \mathrm{L})\end{array}$ & - & 0.2 & 82.4 \\
\hline $\mathrm{BOD}_{5}(\mathrm{mg} / \mathrm{L})$ & 149 & 25 & 75 \\
\hline $\mathrm{COD}(\mathrm{mg} / \mathrm{L})$ & 150 & 70 & 10 \\
\hline $\mathrm{COD} / \mathrm{BOD}_{5}$ & 1 & 2.8 & 0.13 \\
\hline TOC (mg/L) & 164 & 100 & 78 \\
\hline Temperature $\left({ }^{\circ} \mathrm{C}\right)$ & 25 & 28 & 40.5 \\
\hline
\end{tabular}

Time of treatment: $30 \mathrm{~min}$.

demand $\left(\mathrm{BOD}_{5}\right), \mathrm{COD}$, TOC, energy consumption, and efficiency of the anodes. In this context, the authors evaluated

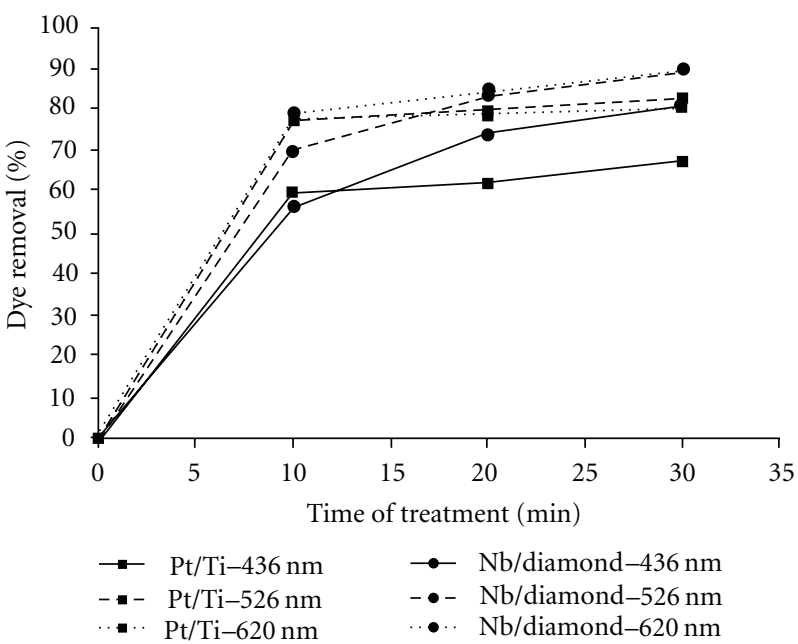

Figure 12: Decoloration efficiency of $\mathrm{Nb} / \mathrm{D}$ and $\mathrm{Pt} / \mathrm{Ti}$, treating real wastewater. Applied potential: $18 \mathrm{~V}$; time of treatment: $30 \mathrm{~min}$ [48].

different experimental conditions such as type and concentration of supporting electrolyte, effect of applied potential, $\mathrm{pH}$, and temperature. Table 2 shows initial and final values of the most important environmental parameters of electrochemically treated wastewater under optimal conditions using both $\mathrm{Pt} / \mathrm{Ti}$ and $\mathrm{Nb} / \mathrm{BDD}$ electrodes. As can be seen, the use of $\mathrm{Nb} / \mathrm{BDD}$ anode increased the efficiency removal for the most important parameters such as $\mathrm{BOD}_{5}, \mathrm{COD}$, TOC, and dye removal. An interesting result was shown in Figure 12, where the authors present the comparison of $\mathrm{Pt} / \mathrm{Ti}$ and $\mathrm{Nb} / \mathrm{BDD}$ electrodes, to treat real wastewater, 


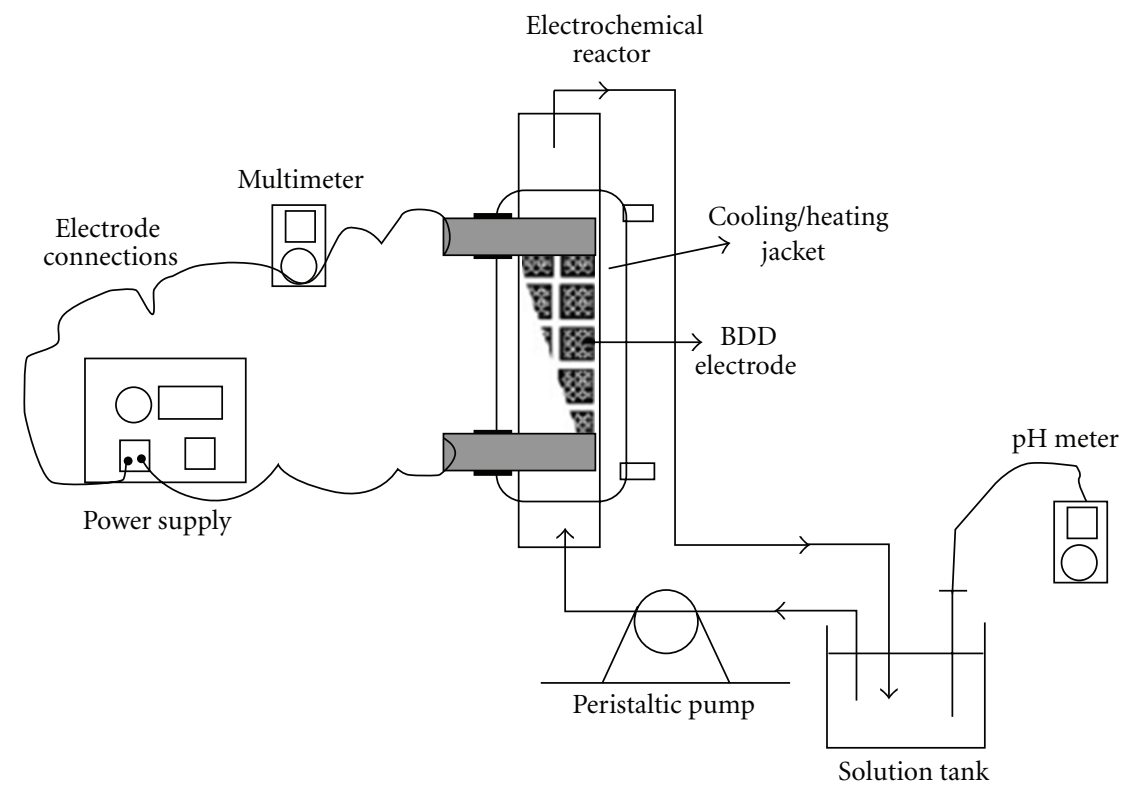

FIgURE 13: Experimental setup used in the studies for the degradation of Basic Red 29 (BR29) [26].

without any further addition of electrolytes. These results clearly indicated that after $30 \mathrm{~min}$ treatment, the rate of decoloration for the two anodes was very similar. However, the $\mathrm{Nb} / \mathrm{BDD}$ achieved a higher decoloration removal (85$90 \%$ ), resulting in practically colorless final wastewater.

Koparal et al. [26] has demonstrated that the electrochemical incineration of Basic Red 29 (BR29) treatment in a bipolar trickle tower (BTT) reactor by using Raschig's ring-shaped $\mathrm{BDD}$ electrodes is an originally setup to this goal. The experimental electrochemical reactor is illustrated in Figure 13. The effects of some important parameters such as initial dye concentration, $\mathrm{Na}_{2} \mathrm{SO}_{4}$ concentration as supporting electrolyte, current density, flow rate, and initial $\mathrm{pH}$ on the removal efficiency were studied. From the results by Koparal et al. [26], the initial COD of real effluent was $566.45 \mathrm{mg} / \mathrm{L}$ and decreased gradually to a final value of $52.38 \mathrm{mg} / \mathrm{L}$ after $8 \mathrm{~h}$ of treatment. A decrease in COD of nearly $91 \%$ was achieved with an energy consumption of $1.4 \mathrm{kWh} / \mathrm{g}$ COD removed. Usually, the toxicity assays for electrochemistry treatments are not performed, However, microtox bioassay tests were performed in this study to assess the textile wastewater treated in the electrochemical reactor in a given time intervals including the time zero. A toxicity result was given as relative toxicity index (RTI), Figure 14. Initial toxicity values showed that wastewater was highly toxic. According to the result, this method was found to be successful for dye and COD removal, indicating that it is also successful for toxicity reduction. As can be seen toxicity reduction was also achieved by using electrochemical oxidation, however, the toxicity was decreased to a lesser extent for textile wastewater.

Interesting research about the electrochemical oxidation of the biotic degradation products of the textile dye C.I. Acid Orange 7 (AO7) was achieved using a BDD electrode by Carvalho and collaborators [27]. They have proposed the use of real effluent obtained from anaerobic sludge

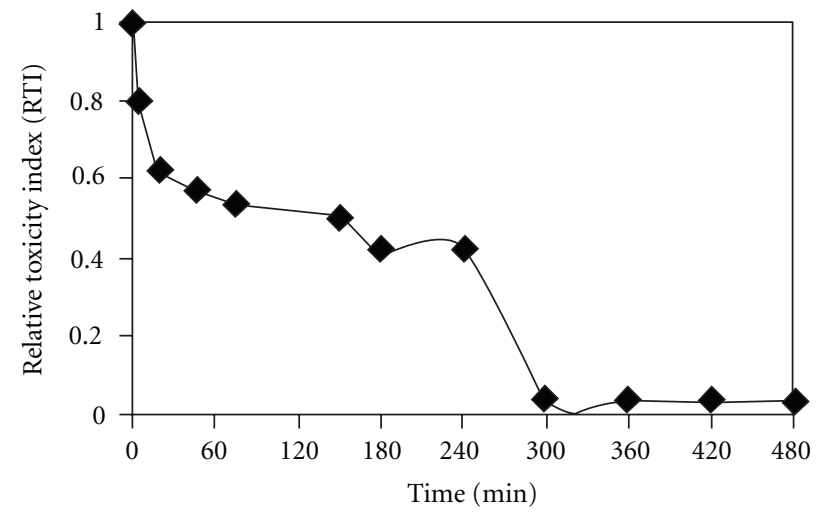

FIgURE 14: Variation of toxicity with time in the textile wastewater ( $i=1 \mathrm{~mA} / \mathrm{cm}^{2}, Q=36.3 \mathrm{~mL} / \mathrm{min}$ ) [26].

blanket (UASB) reactors operating under mesophilic or thermophilic conditions. The electrolysis was studied using two supporting electrolytes: $\mathrm{NaCl}$ and $\mathrm{Na}_{2} \mathrm{SO}_{4}$. The influences of some important variables such as initial metabolite concentration and current density on the electrodegradation rates of the biotic products were analyzed. Table 3 summarizes the results of the removal of COD, TOC, absorbance at $486 \mathrm{~nm}$ (AO7) and $250 \mathrm{~nm}$ (Arom) and relative current efficiency obtained after the electrochemical degradation of the effluents from the UASB reactors. Results have shown that under thermophilic conditions and $20 \mathrm{~mA} \mathrm{~cm}^{-2}$ of applied current density, it is possible to obtain higher removal efficiency of COD (90\%) and TOC (30\%) and diminished absorbance: $\mathrm{Abs}_{286}(100 \%)$ and $\mathrm{Abs}_{250}$ (90\%). These data have demonstrated that BDD anodes could be an important tool for treating real effluents without the use of other chemical reagents or long time periods. 
TABle 3: Removals of COD and TOC, Absorbance at $468 \mathrm{~nm}$ (AO7) and $250 \mathrm{~nm}$ (Arom), and relative current efficiency obtained after the electrochemical degradation of the effluents from the UASB reactors [27].

\begin{tabular}{|c|c|c|c|c|c|c|}
\hline \multirow{2}{*}{$\begin{array}{l}\text { Current } \\
\text { density/mA } \\
\mathrm{cm}^{-2} \text { Electrolyte }\end{array}$} & \multicolumn{3}{|c|}{10} & \multicolumn{3}{|c|}{20} \\
\hline & $\mathrm{N}$ & $S$ & $\mathrm{C}$ & $\mathrm{N}$ & $S$ & $\mathrm{C}$ \\
\hline \multicolumn{7}{|l|}{ Mesophilic } \\
\hline \multicolumn{7}{|l|}{ \% Removal } \\
\hline COD & 45 & 52 & 67 & 72 & 84 & 72 \\
\hline TOC & 41 & 21 & 19 & 31 & 31 & 24 \\
\hline $\mathrm{Abs}_{486}$ & 66 & 77 & 90 & 89 & 100 & 100 \\
\hline $\mathrm{Abs}_{250}$ & 73 & 70 & 75 & 85 & 86 & 81 \\
\hline $\mathrm{EC} / \mathrm{EC}_{\mathrm{N} 20}$ & 0.31 & 0.19 & 0.19 & 1 & 0.57 & 0.52 \\
\hline \multicolumn{7}{|l|}{ Thermophilic } \\
\hline \multicolumn{7}{|l|}{ \% Removal } \\
\hline COD & 54 & 52 & 63 & 83 & 67 & 90 \\
\hline TOC & 30 & 29 & 24 & 31 & 31 & 30 \\
\hline $\mathrm{Abs}_{486}$ & 72 & 43 & 100 & 81 & 81 & 100 \\
\hline $\mathrm{Abs}_{250}$ & 69 & 65 & 77 & 81 & 78 & 91 \\
\hline $\mathrm{EC} / \mathrm{EC}_{\mathrm{N} 20}$ & 0.32 & 0.24 & 0.20 & 1 & 0.58 & 0.51 \\
\hline
\end{tabular}

$\mathrm{N}$ : no added electrolyte, S: sulphate, C: chloride, 10, 20: current densities of 10 and $20 \mathrm{~mA} \mathrm{~cm}^{-2}$, EC: energy consumption, $\mathrm{EC} / \mathrm{EC}_{\mathrm{N} 20}$ : relative efficiencies values are calculated with respect to the assay with no added electrolyte at $20 \mathrm{~mA} \mathrm{~cm}^{-2}$.

On the other hand, Malpass et al. [49] report that about $90 \%$ decolorization was attained only when $\mathrm{NaCl}$ $\left(5.85 \mathrm{~g} \mathrm{~L}^{-1}\right)$ was added to the real textile effluent $(0.25 \mathrm{~L})$, independently of the composition of the DSA anode used; from their data, one may infer that about $16 \mathrm{kC} \mathrm{L}^{-1}$ was used. From all these results, it becomes clear that decolorization by electrooxidation is facilitated by the addition of $\mathrm{Cl}^{-}$ions to the real textile effluent. In other researches, degradation of dye chromophores is more easily attained in the presence of active chlorine. In fact, Malpass et al. [50] showed that complete real textile effluent decolorization could be attained by the direct addition of $\mathrm{OCl}^{-}$ions at a concentration of $\sim 0.50 \mathrm{~g} \mathrm{~L}^{-1}$.

Most relevant applications of anodic oxidation for treating real effluents have been published [51-58]. The electrochemical treatment of acrylic fiber-manufacturing, biorefractory wastewater, simulated ground water containing MTBE and BTEX, tannery wastewater, olive pomace leachate, biologicallypretreated dye wastewater, biologically pretreated coking wastewater, and ink effluents are some examples of the applicability of this technology using BDD anodes.

Diamadopoulos and coworkers [58] studied the effluent treatment from flexographic printing by precipitation/coagulation and electrochemical oxidation over BDD electrodes. Precipitation with $3 \mathrm{~g} / \mathrm{L}$ of lime led to complete removal of effluent turbidity (initial value of about 410 NTU) but only about $20 \%$ decrease in chemical oxygen demand (COD) (initial value of about $1,900 \mathrm{mg} / \mathrm{L}$ ). In addition, higher lime dosages (up to $15 \mathrm{~g} / \mathrm{L}$ ) had no effect on separation. Preliminary electrochemical oxidation experiments in the presence of sulphuric acid as supporting electrolyte showed that treatment performance (in terms of COD removal and decrease in sample absorbance at $300 \mathrm{~nm}$ ) increased with increasing applied current, being more efficient at shorter treatment times and lower currents with efficiency reaching $30 \%$. Following lime precipitation, the effluent was electrochemically oxidized at alkaline conditions for $360 \mathrm{~min}$ yielding $64 \%$ absorbance reduction and $50 \%$ COD removal (this corresponds to $60 \%$ overall COD removal for the combined process). Finally, they attributed the slightly low electrochemical treatment performance to limestone deposition and fouling of electrodes and other electrochemical reactor components, as evidenced by the gradual drop in conductivity/current throughout the operation.

In another case, the electrochemical treatment of acrylic fiber-manufacturing wastewater (AFMW) with BDD electrode was investigated by Zhang et al. [51]. A factorial design methodology was employed to evaluate the statistically important operating variables of treatment time (1-2 h), flow rate $(400-600 \mathrm{~mL} / \mathrm{min})$, current intensity $(0.50-1.00 \mathrm{~A})$, and initial COD load (362-723 mg/L) on the treatment efficiency. The latter was assessed in terms of COD and ammonianitrogen $\left(\mathrm{NH}_{3}-\mathrm{N}\right)$ removal. The results clearly demonstrated the suitability of the BDD technology for COD removal, as well as the unique behavior in removing $\mathrm{NH}_{3}-\mathrm{N}$. However, they performed a comparison electrochemical treatment between DSA and BDD anodes in order to understand both behaviors. These results showed great potential of the BDD technology to be an effective option for treating AFMW, due to the efficient reduction of COD, energy consumption and treatment time in respect to the DSA anode, as shown in Figure 15. The excellent performance of the BDD technology might be attributed to the presence of free hydroxyl radicals generated on nonactive BDD electrode, as well as the chloride-free nature of AFMW.

A practical application of electrochemical oxidation in biorefractory wastewater treatment was performed by Zhu et al. [52]. In this study, the performance of a smaller BDD anode $\left(24 \mathrm{~cm}^{2}\right)$ system in a continuous mode of electrochemical oxidation of phenol-simulated wastewater was first investigated. The performance was described by the response surface methodology (RSM). Next, the RSM was extended to examine the scale-up feasibility of BDD anode systems with similar configurations. They demonstrated that both COD degradation efficiency and specific energy consumption could be expected at the same level even as the system was enlarged over 100 times, which implied that BDD anode system could be successfully scaled up through controlling the same retention time, current density, initial COD, and conductivity conditions. Based on this study, a larger BDD anode $\left(2904 \mathrm{~cm}^{2}\right)$ system was constructed, and systematic measurements were made on its performance in the electrochemical oxidation of phenol-simulated wastewater. Under optimumconditions, the larger BDD anode system easily reduced the COD of phenol simulated wastewater from $633 \mathrm{mg} \mathrm{L}^{-1}$ to $145 \mathrm{mg} \mathrm{L}^{-1}\left(<150 \mathrm{mg} \mathrm{L}^{-1}\right.$, National Discharge Standard of China) during $80 \mathrm{~min}$ with specific energy 


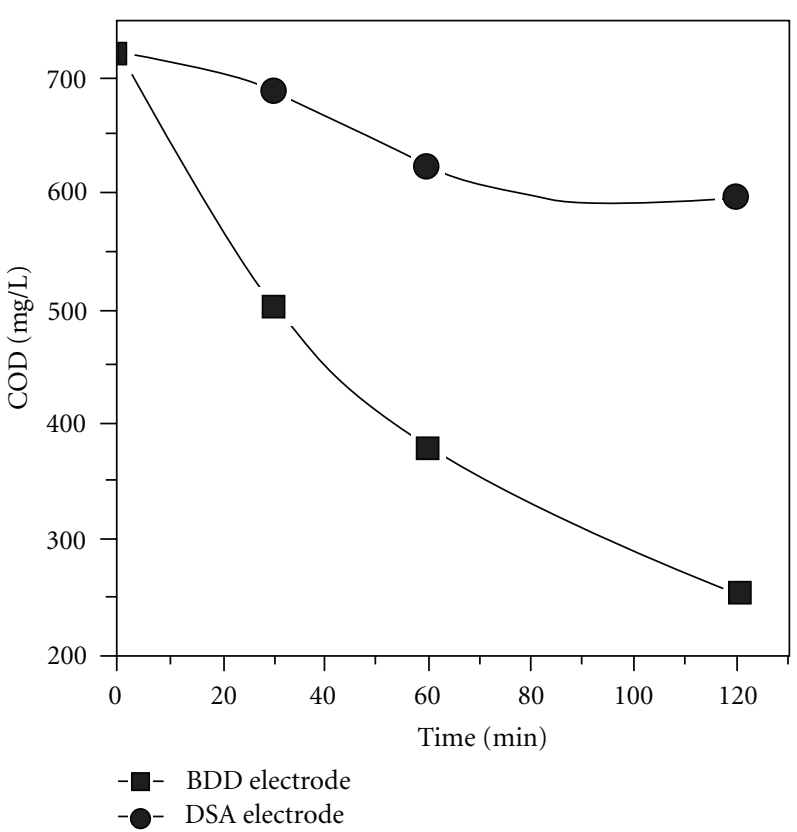

(a)

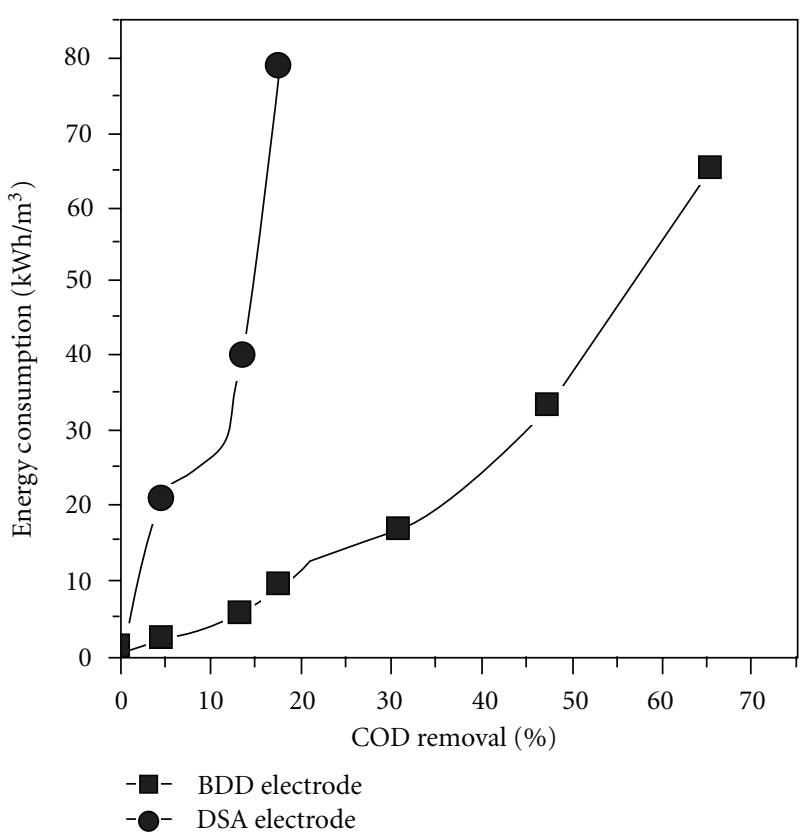

(b)

FIGURE 15: (a) Comparison of the evolution of COD during electrochemical treatment; (b) evolution of the specific energy consumption against COD removal during electrochemical treatment of acrylic fiber wastewater on DSA and BDD electrode. Conditions: applied current: $0.50 \mathrm{~A}$, flow rate: $400 \mathrm{~mL} / \mathrm{min}, T=45 \pm 1^{\circ} \mathrm{C}$ [51].

consumption of only $31 \mathrm{kWh} \mathrm{kgCOD}^{-1}$. These engineering results can motivate other research groups to employ BDD anodes to scale up this electrochemical process.

Coking wastewater contains high concentrations of refractory and toxic compounds, and the water quality usually cannot meet the discharge standards after conventional biological treatment processes. For this reason, the electrochemical oxidation using BDD anode for advanced treatment of coking wastewater was investigated by Zhu et al. [59]. Under the experimental conditions (current density 20-60 $\mathrm{mA} \mathrm{cm}^{-2}, \mathrm{pH} \mathrm{3-11}$, and temperature $20-60^{\circ} \mathrm{C}$ ) using a BDD anode, complete mineralization of organic pollutants was almost achieved. Surplus ammonia-nitrogen $\left(\mathrm{NH}_{3}-\mathrm{N}\right)$ was further removed thoroughly when $\mathrm{pH}$ was not adjusted at alkaline value. Moreover, the TOC and $\mathrm{NH}_{3}-\mathrm{N}$ removal rates in the $\mathrm{BDD}$ anode cell were much greater than those in other common anode systems such as $\mathrm{SnO}_{2}$ and $\mathrm{PbO}_{2}$ anode cells. Also, the energy consumption of $64 \mathrm{kWh} \mathrm{kgCOD}^{-1}$ observed in the BDD anode system was only about $60 \%$ as much as those observed in $\mathrm{SnO}_{2}$ and $\mathrm{PbO}_{2}$ anode systems. Other results reported by these authors revealed that, in the BDD anode cell, organic pollutants were mainly degraded by reaction with free hydroxyl radicals, and electrogenerated oxidants $\left(\mathrm{S}_{2} \mathrm{O}_{8}{ }^{2-}, \mathrm{H}_{2} \mathrm{O}_{2}\right.$, and other oxidants) played a less important role. Direct electrochemical oxidation and indirect electrochemical oxidation mediated by active chlorine can be negligible. These results showed great potential of $\mathrm{BDD}$ anode systems in engineering applications as a final treatment of coking wastewater.

A synthetic tannery wastewater, prepared with several compounds used by finishing tanneries, was studied in chloride-free media [54] comparing the efficiency removal at different anode materials: $\mathrm{Si} / \mathrm{BDD}, \mathrm{Ti} / \mathrm{SnO}_{2}-\mathrm{Sb}$, and $\mathrm{Ti} / \mathrm{SnO}_{2}-\mathrm{Sb}-\mathrm{Ir}$. The influence of $\mathrm{pH}$ and current density on the treatment was assessed by measuring total phenols, COD, TOC, and absorbance. Results showed that faster decrease in these parameters occurred when the Si/BDD anode was used (see Figure 16). Good results were obtained with the $\mathrm{Ti} / \mathrm{SnO}_{2}-\mathrm{Sb}$ anode, but its complete deactivation was reached after $4 \mathrm{~h}$ of electrolysis at $25 \mathrm{~mA} \mathrm{~cm}^{-2}$, indicating that the service life of this electrode was short. The Ti/ $\mathrm{SnO}_{2}-$ $\mathrm{Sb}-\mathrm{Ir}$ anode is chemically and electrochemically more stable than the $\mathrm{Ti} / \mathrm{SnO}^{2}-\mathrm{Sb}$ anode, but it was not suitable for the electrochemical treatment under the studied conditions in this research. According to the authors, no significant changes were observed for electrolysis performed at different $\mathrm{pH}$ conditions with $\mathrm{Si} / \mathrm{BDD}$, and this electrode led to almost complete mineralization after $4 \mathrm{~h}$ of electrolysis at $100 \mathrm{~mA} \mathrm{~cm}^{-2}$. The increase in current density resulted in faster wastewater oxidation, with lower current efficiency and higher energy consumption. Si/BDD proved to be the best electrodic material for the direct electrooxidation of tannery wastewaters.

Moreover, the results published by these authors are evidence that electrooxidation in chloride-free media is more advantageous than that carried out in chloride-containing media because it avoids formation of toxic organochloride compounds.

\section{Concluding Remarks}

This paper summarizes the most relevant investigations carried out on electrochemical treatment processes for 


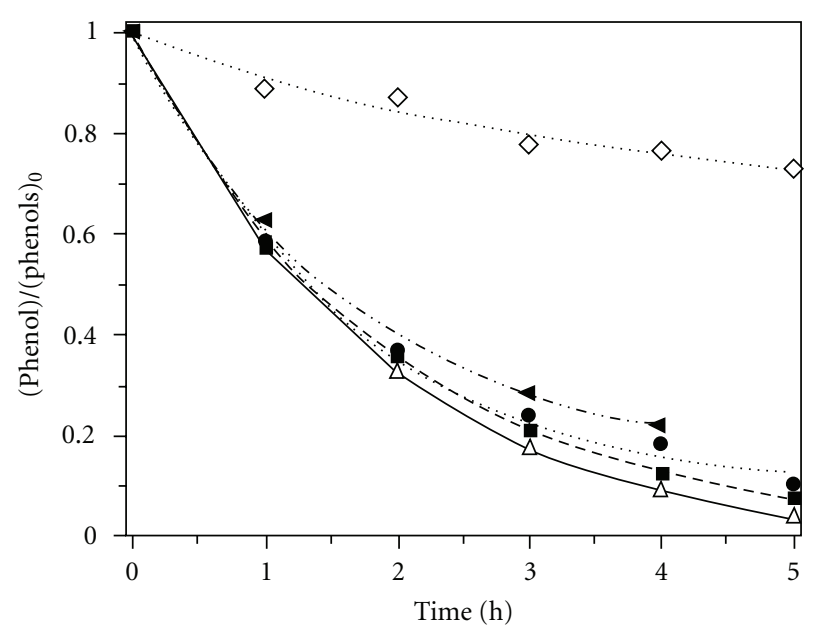

(a)

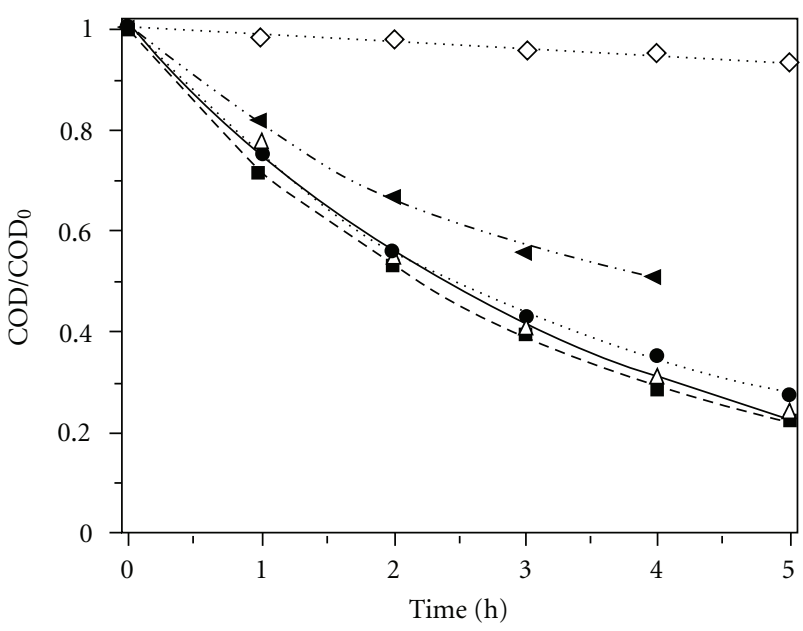

(b)

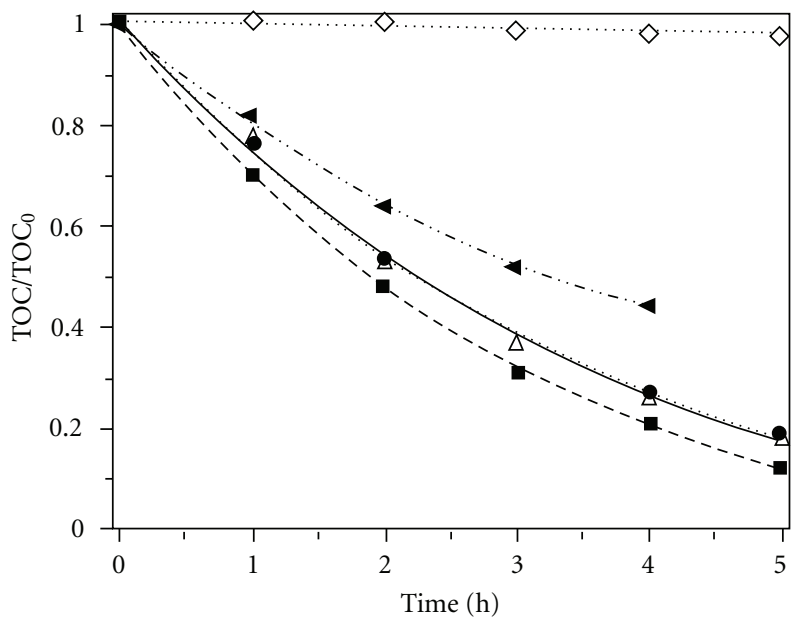

(c)

FIGURE 16: Effect of the electrodic material and $\mathrm{pH}$ on the electrooxidation of the synthetic tannery wastewater in $0.10 \mathrm{~mol} \mathrm{~L}^{-1} \mathrm{Na}_{2} \mathrm{SO}_{4}$ at

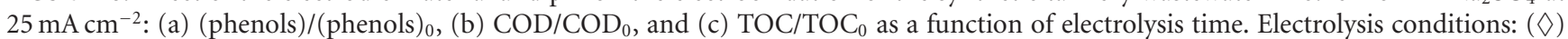
$\mathrm{Ti} / \mathrm{SnO}_{2}-\mathrm{Sb}-\mathrm{Ir}$ and $\mathrm{pH} 2.4,(\triangleleft) \mathrm{Ti} / \mathrm{SnO}_{2}-\mathrm{Sb}$ and $\mathrm{pH} 2.4,(\boldsymbol{\square}) \mathrm{Si} / \mathrm{BDD}$ and $\mathrm{pH} 2.4,(\bullet) \mathrm{Si} / \mathrm{BDD}$ and $\mathrm{pH} 7.3$, and $(\triangle) \mathrm{Si} / \mathrm{BDD}$ and $\mathrm{pH} 12.0$ [54].

oxidation of synthetic dye compounds with the use of BDD anodes. The efficiency of these electrochemical processes seems to be strongly dependent on parameters such as synthetic dye concentration, $\mathrm{pH}$, applied current intensity, and supporting electrolyte, but the most important parameter is the kind of electrode material. As was mentioned, several authors tested different surfaces, such as Ti/BDD, $\mathrm{Ti} / \mathrm{Sb}_{2} \mathrm{O}_{5}-\mathrm{SnO}_{2}, \mathrm{Pt} / \mathrm{Ti}, \mathrm{TiRuO}_{2}$, and $\mathrm{PbO}_{2}$ in order to evaluate an anode material with the best conditions with respect to high stability, high activity towards organic oxidation and low cost. However, BDD anodes always offer the most advantages regarding removal efficiency and decontamination of wastewaters. The cost of BDD application could be limited due to the price of $\mathrm{BDD}$ anode preparation and fragility of the required electrocatalytic materials. Additionally, electrical potentials exhibited by electrochemical oxidation processes using BDD anodes increase energy consumption, limiting the use in industrial application.
Perhaps, the key will be to use integrated methods or BDD electrochemical technologies coupled with other advanced oxidation processes.

Moreover, according to the results reported by other authors and in view of a concern for environmental protection, the advantages of BDD, high oxygen evolution potential, and low chlorine evolution potential will make it take precedence over other electrodes in the degradation of chloride-free dye wastewater. Therefore, in practical applications, the degradation of chloride-free wastewaters, especially the degradation of those in water supply and drainage system, should be performed on BDD electrodes rather than DSA for the sake of environmental protection in spite of high energy and time consumption. However, for effluents from industries and domestic sewage that contain $\mathrm{Cl}^{-}$ions, electrochemical degradation should be carried out on DSA anodes, due to the higher energy requirements and lower removal efficiencies when using BDD anodes. 


\section{Acknowledgments}

The authors thank Eng. N. Claudia Calderón Rosas and Eng. Leslie Knapp (cooperante sponsored by the US Peace Corps under agreement with CONACYT) for their help in the manuscript revision. The authors thank the CIATEC Ref.003/CEP/2011 for financial support.

\section{References}

[1] C. Fernández, M. S. Larrechi, and M. P. Callao, "An analytical overview of processes for removing organic dyes from wastewater effluents," Trends in Analytical Chemistry, vol. 29, no. 10, pp. 1202-1211, 2010.

[2] A. B. Dos Santos, F. J. Cervantes, and J. B. Van Lier, "Review paper on current technologies for decolourisation of textile wastewaters: perspectives for anaerobic biotechnology," Bioresource Technology, vol. 98, no. 12, pp. 2369-2385, 2007.

[3] A. Srinivasan and T. Viraraghavan, "Decolorization of dye wastewaters by biosorbents: a review," Journal of Environmental Management, vol. 91, no. 10, pp. 1915-1929, 2010.

[4] C. Baiocchi, M. C. Brussino, E. Pramauro, A. B. Prevot, L. Palmisano, and G. Marcí, "Characterization of methyl orange and its photocatalytic degradation products by HPLC/UV-VIS diode array and atmospheric pressure ionization quadrupole ion trap mass spectrometry," International Journal of Mass Spectrometry, vol. 214, no. 2, pp. 247-256, 2002.

[5] V. Augugliaro, C. Baiocchi, A. B. Prevot et al., "Azo-dyes photocatalytic degradation in aqueous suspension of $\mathrm{TiO}_{2}$ under solar irradiation," Chemosphere, vol. 49, no. 10, pp. 1223-1230, 2002.

[6] J. M. Peralta-Hernández, C. A. Martínez-Huitle, J. L. GuzmánMar, and A. Hernández-Ramírez, "Recent advances in the application of electro-Fenton and photoelectro-Fenton process for removal of synthetic dyes in wastewater treatment," Journal of Environmental Engineering Management, vol. 19, no. 5, pp. 257-265, 2009.

[7] C. A. Martínez-Huitle and S. Ferro, "Electrochemical oxidation of organic pollutants for the wastewater treatment: direct and indirect processes," Chemical Society Reviews, vol. 35, no. 12, pp. 1324-1340, 2006.

[8] J. M. Peralta-Hernández, S. Mejía, L. A. Godínez, and Y. MeasVong, "Fenton and electrochemical approaches for water purification technologies," in Applications of Analytical Chemistry in Environmental Research, M. Palomar, Ed., Research Signpost, Kerala, India, 2005.

[9] K. Jüttner, U. Galla, and H. Schmieder, "Electrochemical approaches to environmental problems in the process industry," Electrochimica Acta, vol. 45, no. 15-16, pp. 2575-2594, 2000.

[10] Ch. Comninellis, "Electrocatalysis in the electrochemical conversion/combustion of organic pollutants for waste water treatment," Electrochimica Acta, vol. 39, no. 11-12, pp. 1857$1862,1994$.

[11] M. Panizza, E. Brillas, and Ch. Comninellis, "Application of boron-doped diamond electrodes for wastewater treatment," Journal of Environmental Engineering Management, vol. 18, no. 3, pp. 139-153, 2008.

[12] F. Montilla, P. A. Michaud, E. Morallón, J. L. Vázquez, and Ch. Comninellis, "Electrochemical oxidation of benzoic acid at boron-doped diamond electrodes," Electrochimica Acta, vol. 47, no. 21, pp. 3509-3513, 2002.
[13] S. Songa, L. Zhan, Z. Hea et al., "Mechanism of the anodic oxidation of 4-chloro-3-methyl phenol in aqueous solution using $\mathrm{Ti} / \mathrm{SnO}_{2}-\mathrm{Sb} / \mathrm{PbO}_{2}$ electrodes," Journal of Hazardous Materials, vol. 175, no. 1-3, pp. 614-621, 2010.

[14] Ch. Tan, B. Xiang, Y. Li, J. Fang, and M. Huang, "Preparation and characteristics of a nano- $\mathrm{PbO}_{2}$ anode for organic wastewater treatment," Chemical Engineering Journal, vol. 166, no. 1, pp. 15-21, 2011.

[15] G. B. Raju, M. T. Karuppiah, S. S. Latha, D. Latha Priya, S. Parvathy, and S. Prabhakar, "Electrochemical pretreatment of textile effluents and effect of electrode materials on the removal of organics," Desalination, vol. 249, no. 1, pp. 167$174,2009$.

[16] C. A. Martínez-Huitle and E. Brillas, "Decontamination of wastewaters containing synthetic organic dyes by electrochemical methods: a general review," Applied Catalysis B, vol. 87, no. 3-4, pp. 105-145, 2009.

[17] O. Simond, V. Schaller, and Ch. Comninellis, "Theoretical model for the anodic oxidation of organics on metal oxide electrodes," Electrochimica Acta, vol. 42, no. 13-14, pp. 20092012, 1997.

[18] M. Panizza and G. Cerisola, "Application of diamond electrodes to electrochemical processes," Electrochimica Acta, vol. 51, no. 2, pp. 191-199, 2005.

[19] X. Chen, G. Chen, and P.-L. Yue, "Anodic oxidation of dyes at novel Ti/B-diamond electrodes," Chemical Engineering Science, vol. 58, no. 3-6, pp. 995-1001, 2003.

[20] P. Cañizares, A. Gadri, J. Lobato et al., "Electrochemical oxidation of azoic dyes with conductive-diamond anodes," Industrial and Engineering Chemistry Research, vol. 45, no. 10, pp. 3468-3473, 2006.

[21] A. Sakalis, K. Fytianos, U. Nickel, and A. Voulgaropoulos, "A comparative study of platinised titanium and niobe/synthetic diamond as anodes in the electrochemical treatment of textile wastewater," Chemical Engineering Journal, vol. 119, no. 2-3, pp. 127-133, 2006.

[22] M. Panizza, A. Barbucci, R. Ricotti, and G. Cerisola, "Electrochemical degradation of methylene blue," Separation and Purification Technology, vol. 54, no. 3, pp. 382-387, 2007.

[23] M. Panizza and G. Cerisola, "Electrochemical degradation of methyl red using $\mathrm{BDD}$ and $\mathrm{PbO}_{2}$ anodes," Industrial and Engineering Chemistry Research, vol. 47, no. 18, pp. 6816-6820, 2008.

[24] M. Panizza and G. Cerisola, "Removal of colour and COD from wastewater containing acid blue 22 by electrochemical oxidation," Journal of Hazardous Materials, vol. 153, no. 1-2, pp. 83-88, 2008.

[25] N. Bensalah, M. A. Q. Alfaro, and C. A. Martínez-Huitle, "Electrochemical treatment of synthetic wastewaters containing Alphazurine A dye," Chemical Engineering Journal, vol. 149, no. 1-3, pp. 348-352, 2009.

[26] A. S. Koparal, Y. Yavuz, C. Gürel, and Ü. B. Öğütveren, "Electrochemical degradation and toxicity reduction of C.I. Basic Red 29 solution and textile wastewater by using diamond anode," Journal of Hazardous Materials, vol. 145, no. 1-2, pp. 100-108, 2007.

[27] C. Carvalho, A. Fernandes, A. Lopes, H. Pinheiro, and I. Goncalves, "Electrochemical degradation applied to the metabolites of Acid Orange 7 anaerobic biotreatment," Chemosphere, vol. 67, no. 7, pp. 1316-1324, 2007.

[28] C. Saez, M. Panizza, M. A. Rodrigo, and G. Cerisola, "Electrochemical incineration of dyes using a boron-doped diamond anode," Journal of Chemical Technology and Biotechnology, vol. 82 , no. 6, pp. 575-581, 2007. 
[29] D. Montanaro and E. Petrucci, "Electrochemical treatment of Remazol Brilliant Blue on a boron-doped diamond electrode," Chemical Engineering Journal, vol. 153, no. 1-3, pp. 138-144, 2009.

[30] J. Rodriguez, M. A. Rodrigo, M. Panizza, and G. Cerisola, "Electrochemical oxidation of Acid Yellow 1 using diamond anode," Journal of Applied Electrochemistry, vol. 39, no. 11, pp. 2285-2289, 2009.

[31] Ch. Zhang and J. Wang, "Influence of cations during OrangeII degradation on boron-doped diamond electrode," Journal of Electroanalytical Chemistry, vol. 638, no. 1, pp. 91-99, 2010.

[32] L. S. Andrade and T. T. Tasso, "On the performances of lead dioxide and boron-doped diamond electrodes in the anodic oxidation of simulated wastewater containing the Reactive Orange 16 dye," Electrochimica Acta, vol. 54, no. 7, pp. 20242030, 2009.

[33] E. Hmani, S. Chaabane Elaoud, and Y. Samet, "Electrochemical degradation of waters containing O-Toluidine on $\mathrm{PbO}_{2}$ and BDD anodes," Journal of Hazardous Materials, vol. 170, no. 2-3, pp. 928-933, 2009.

[34] Y. Yavuz, A. Savaş Koparal, and Ü. B. Öğütveren, "Electrochemical oxidation of Basic Blue 3 dye using a diamond anode: evaluation of colour, COD and toxicity removal," Journal of Chemical Technology and Biotechnology, vol. 86, no. 2, pp. 261265, 2011.

[35] C. R. Costa, F. Montilla, and E. Morallón, "Electrochemical oxidation of acid black 210 dye on the boron-doped diamond electrode in the presence of phosphate ions: effect of current density, pH, and chloride ions," Electrochimica Acta, vol. 54, no. 27, pp. 7048-7055, 2009.

[36] K. E. Carter and J. Farrell, "Electrochemical oxidation of trichloroethylene using boron-doped diamond film electrodes," Environmental Science and Technology, vol. 43, no. 21, pp. 8350-8354, 2009.

[37] M. Wu, G. Zhao, M. Li, L. Liu, and D. Li, "Applicability of boron-doped diamond electrode to the degradation of chloride-mediated and chloride-free wastewaters," Journal of Hazardous Materials, vol. 163, no. 1, pp. 26-31, 2009.

[38] M. J. Pacheco, V. Santos, L. Ciríaco, and A. Lopes, "Electrochemical degradation of aromatic amines on BDD electrodes," Journal of Hazardous Materials, vol. 186, no. 2-3, pp. 10331041, 2011.

[39] M. Zhou, H. Särkkä, and M. Sillanpää, "A comparative experimental study on methyl orange degradation by electrochemical oxidation on BDD and MMO electrodes," Separation and Purification Technology, vol. 78, no. 3, pp. 290-297, 2011.

[40] Ch. Zhang, L. Gu, and Y. Lin, "Degradation of X-3B dye by immobilized $\mathrm{TiO}_{2}$ photocatalysis coupling anodic oxidation on BDD electrode," Journal of Photochemistry and Photobiology A, vol. 207, no. 1, pp. 66-72, 2009.

[41] J. Sun, H. Lu, L. Du, and H. Lin, "Anodic oxidation of anthraquinone dye Alizarin Red S at Ti/BDD electrodes," Applied Surface Science, vol. 257, no. 15, pp. 6667-6671, 2011.

[42] V. Santos, J. Diogo, M. J. A. Pacheco, L. Ciriaco, A. Morao, and A. Lopes, "Electrochemical degradation of sulfonated amines on SI/BDD electrodes," Chemosphere, vol. 79, no. 6, pp. 637645, 2010.

[43] M. Panizza and G. Cerisola, "Electrochemical degradation of gallic acid on a BDD anode," Chemosphere, vol. 77, no. 8, pp. 1060-1064, 2009.

[44] R. E. Palma-Goyes, F. L. Guzmán-Duque, G. Peñuela, I. González, J. L. Nava, and R. A. Torres-Palma, "Electrochemical degradation of crystal violet with BDD electrodes: effect of electrochemical parameters and identification of organic byproducts," Chemosphere, vol. 81, no. 1, pp. 26-32, 2010.

[45] G. R. P. Malpass, D. W. Miwa, D. A. Mortari, S. A. S. Machado, and A. J. Motheo, "Decolorisation of real textile waste using electrochemical techniques: effect of the chloride concentration," Water Research, vol. 41, no. 13, pp. 2969-2977, 2007.

[46] L. S. Andrade and T. T. Tasso, "On the performances of lead dioxide and boron-doped diamond electrodes in the anodic oxidation of simulated wastewater containing the Reactive Orange 16 dye," Electrochimica Acta, vol. 54, no. 7, pp. 20242030, 2009.

[47] E. Chatzisymeon, N. P. Xekoukoulotakis, A. Coz, N. Kalogerakis, and D. Mantzavinos, "Electrochemical treatment of textile dyes and dyehouse effluents," Journal of Hazardous Materials, vol. 137, no. 2, pp. 998-1007, 2006.

[48] S. K. Fytianos, U. Nickel, and A. Voulgaropoulos, "A comparative study of platinised titanium and niobe/synthetic diamond as anodes in the electrochemical treatment of textile wastewater," Chemical Engineering Journal, vol. 119, no. 2-3, pp. 127-133, 2006.

[49] G. R. P. Malpass, D. W. Miwa, S. A. S. Machado, and A. J. Motheo, "Decolourisation of real textile waste using electrochemical techniques: effect of electrode composition," Journal of Hazardous Materials, vol. 156, no. 1-3, pp. 170-177, 2008.

[50] G. R. P. Malpass, D. W. Miwa, D. A. Mortari, S. A. S. Machado, and A. J. Motheo, "Decolorisation of real textile waste using electrochemical techniques: effect of the chloride concentration," Water Research, vol. 41, no. 13, pp. 2969-2977, 2007.

[51] C. Y. Zhanga, J. .L. Wang, H. F. Zhou, D. Fua, and Z. Gu, "Anodic treatment of acrylic fiber manufacturing wastewater with boron-doped diamond electrode: a statistical approach," Chemical Engineering Journal, vol. 161, no. 1-2, pp. 93-98, 2010.

[52] X. Zhu, J. Ni, and J. Wei, "Scale-up of BDD anode system for electrochemical oxidation of phenol simulated wastewater in continuous mode," Journal of Hazardous Materials, vol. 184, no. 1-3, pp. 493-498, 2010.

[53] M. Mascia, A. Vacca, and A. M. Polcaro, "Electrochemical treatment of simulated ground water containing MTBE and BTEX with BDD anodes," Journal of Chemical Technology \& Biotechnology, vol. 86, no. 1, pp. 128-137, 2010.

[54] C. R. Costa, F. Montilla, and E. Morallón, "Electrochemical oxidation of synthetic tannery wastewater in chloride-free aqueous media," Journal of Hazardous Materials, vol. 180, no. 1-3, pp. 429-435, 2010.

[55] P. Grafias and N. P. Xekoukoulotakis, "Pilot treatment of olive pomace leachate by vertical-flow constructed wetland and electrochemical oxidation: an efficient hybrid process," Water Research, vol. 44, no. 9, pp. 2773-2780, 2010.

[56] X. Zhu, J. Ni, and J. Wei, "Destination of organic pollutants during electrochemical oxidation of biologically-pretreated dye wastewater using boron-doped diamond anode," Journal of Hazardous Materials, vol. 189, no. 1-2, pp. 127-133, 2011.

[57] X. Zhu and J. Ni, "Advanced treatment of biologically pretreated coking wastewater by electrochemical oxidation using boron-doped diamond electrodes," Water Research, vol. 43 , no. 17, pp. 4347-4355, 2009. 
[58] E. Diamadopoulos, H. Barndõk, N. P. Xekoukoulotakis, and D. Mantzavinos, "Treatment of ink effluents from flexographic printing by lime precipitation and boron-doped diamond (BDD) electrochemical oxidation," Water Science and Technology, vol. 60, no. 10, pp. 2477-2483, 2009.

[59] X. Zhu, J. Ni, and P. Lai, "Advanced treatment of biologically pretreated coking wastewater by electrochemical oxidation using boron-doped diamond electrodes," Water Research, vol. 43, no. 17, pp. 4347-4355, 2009. 


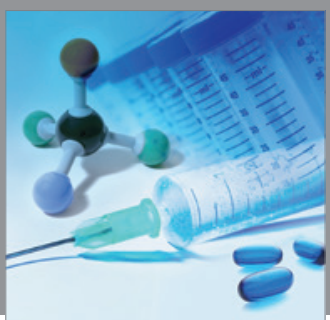

International Journal of

Medicinal Chemistry

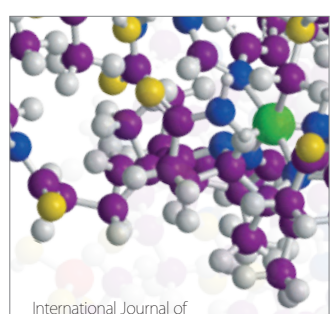

Carbohydrate Chemistry

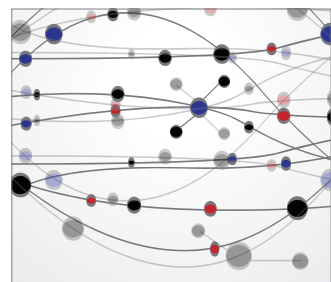

The Scientific World Journal
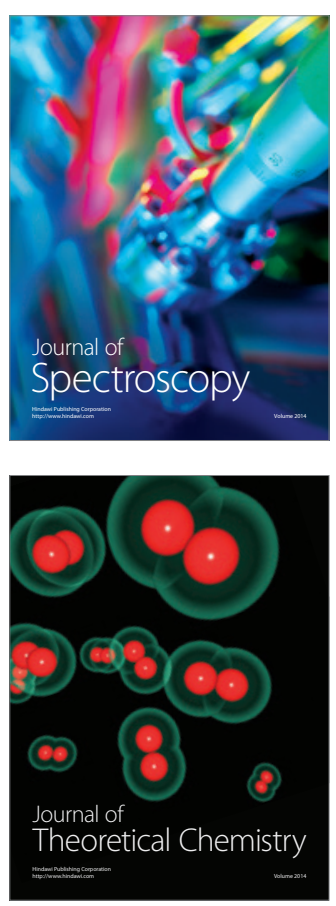
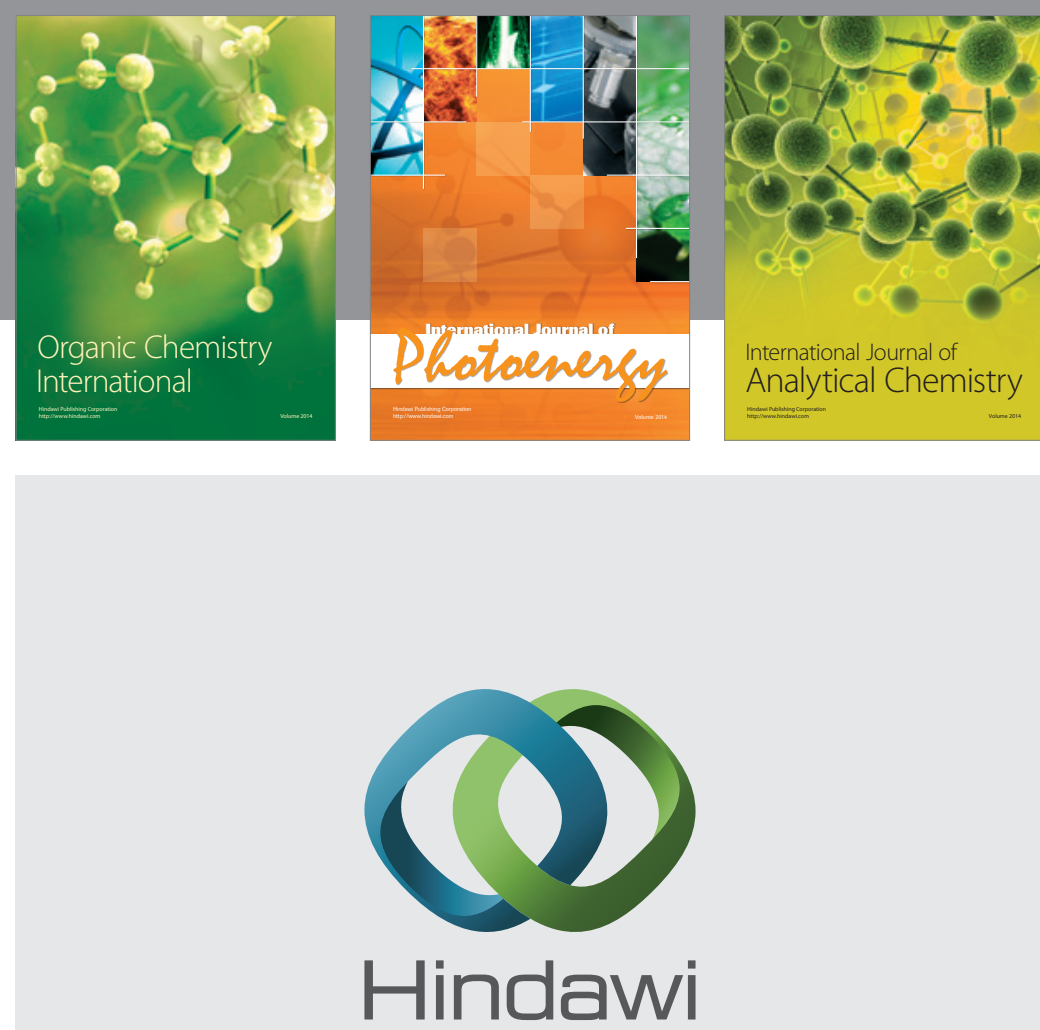

Submit your manuscripts at

http://www.hindawi.com
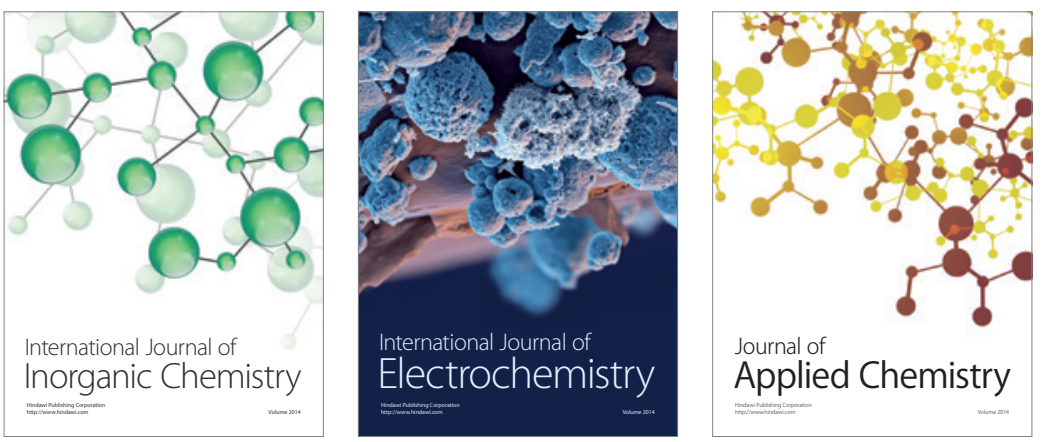

Journal of

Applied Chemistry
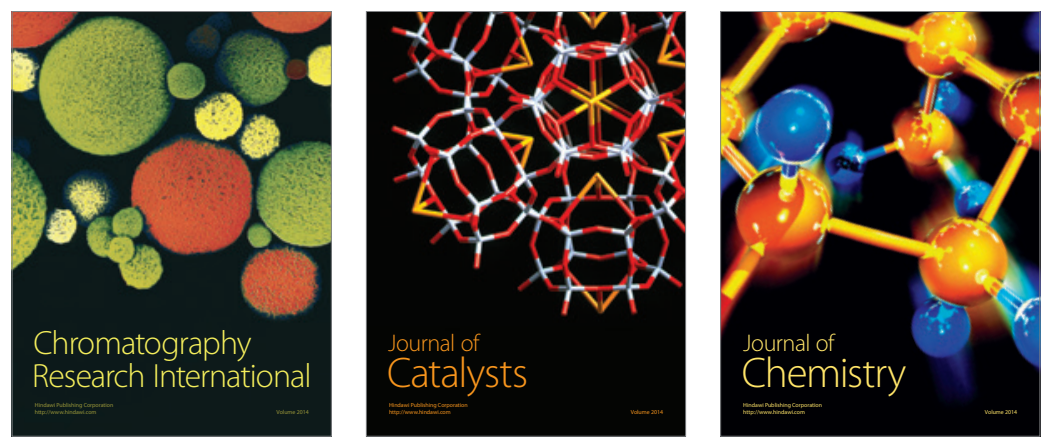
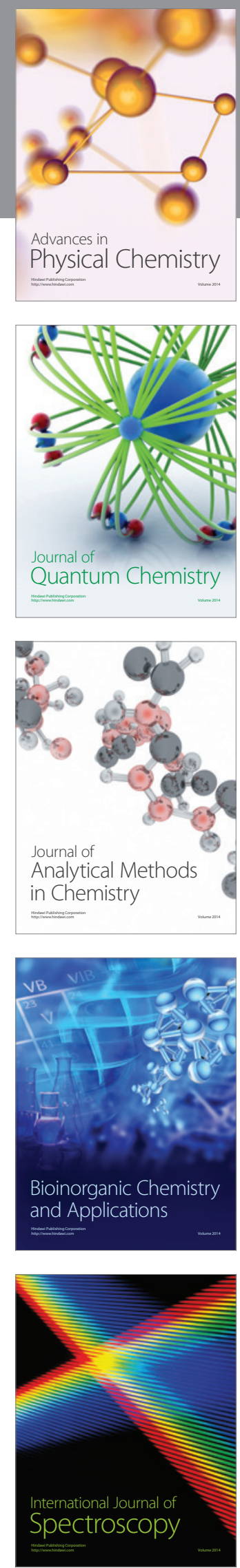